\title{
From the Laboratory to the Kitchen: New Alternatives to Healthier Bakery Products
}

\author{
Miguel Peris ${ }^{1, *}$, Susana Rubio-Arraez ${ }^{2}$, María Luisa Castelló ${ }^{2}$ and María Dolores Ortolá ${ }^{2}$ \\ 1 Department of Chemistry, Universitat Politècnica de València, Camino de Vera, s/n. 46022 Valencia, Spain \\ 2 Institute of Food Engineering for Development, Universitat Politècnica de València, Camino de Vera, s/n. \\ 46022 Valencia, Spain; suruar@upvnet.upv.es (S.R.-A.); mcasgo@upvnet.upv.es (M.L.C.); \\ mdortola@tal.upv.es (M.D.O.) \\ * Correspondence: mperist@qim.upv.es
}

Received: 25 October 2019; Accepted: 5 December 2019; Published: 9 December 2019

check for updates

\begin{abstract}
Due to the growing interest in improving the nutritional profile of bakery products, we have dealt with the most recent and relevant contributions regarding potential replacements for carbohydrates, proteins, and fats. Focusing on the influence of carbohydrates on metabolism, their excess implies obesity, diabetes and tooth decay. However, they are technologically important, since they are responsible for the structure of many bakery products. Regarding of the lipid profile, saturated fats have a great impact on the appearance of cardiovascular disease. Fortunately, nature and the food industry offer alternatives to traditional oils/butters with large amounts of omega 3 and other components that can mitigate these problems. Other relevant aspects are related to allergies concerning egg proteins, gluten or even requirements for vegan consumers. Several studies have been performed in this line, replacing eggs with milk serum, different mucilages obtained from legumes or some gums, etc. In conclusion, many papers have been published showing the possibility of successfully replacing (both at technological and sensory levels) less healthy ingredients with others that are nutritionally better. The challenge now is to combine these better components in a given product, as well as to evaluate possible interactions among them.
\end{abstract}

Keywords: bakery; sweeteners; fat; protein; fiber

\section{Introduction}

The usual consumption of bakery products presents certain drawbacks related to their high content of simple sugars of rapid absorption, high fat content and low amount of dietary fiber, which make them highly caloric foods. Bakery products, including biscuits, cakes and bread, contain wheat flour as primary ingredient as it contributes to structure and volume [1-3]. According to recent data published by the World Health Organization (WHO) [4], 13\% of the world's adult population (11\% of men and $15 \%$ of women) are clinically obese and $39 \%$ of adults aged 18 or older $(40 \%$ of women and $38 \%$ of men) were found to be overweight. Regarding the child population, 41 million children under five are overweight or obese. Overweight and obesity are closely related to the increase in the intake of fat-rich high-calorie foods, as well as to the decrease in physical activity due to the progressively sedentary nature of many types of work, new transportation means and growing development [5].

In human nutrition, fat is an important ingredient in many foods used to improve product excellence [6,7]. Unfortunately, obesity and overweight are the main risk factors for noncommunicable illnesses, such as diabetes, cardiovascular diseases, and some types of cancer. Instead, the excessive consumption of simple sugars, along with their contribution to caloric intake, is related to the development of dental caries. Dental diseases are the most prevalent noncommunicable sicknesses in the world and their treatment consumes between $5 \%$ and $10 \%$ of healthcare budgets in industrialized 
countries [4]. Additionally, simple sugars of rapid absorption cause glycemic peaks and the excess sugar can rapidly become fat in the body [8-10].

Sucrose is a very important ingredient in bakery products for its conservation characteristics and a significant source of energy [11]. Moreover, there is a growing interest in replacing sucrose with alternative substances, such as low-calorie sweeteners (sucralose, tagatose, maltitol, stevia), in bakery products [12]. On the other hand, Trans Fatty Acids (TFA) are associated with an increased risk of coronary heart diseases, affecting inflammation factors and blood lipids [13].

Therefore, the World Health Organization, in its latest report [5], considers it urgent to carry out an immediate reduction in the extreme consumption of sugars and other fast-absorbing carbohydrates such as sucrose, as well as an increase in daily physical activity, to curb the tendency towards obesity and type 2 diabetes. Fortunately, consumers are well aware of the glycemic index (GI), caloric and dietary fiber content of foods. Furthermore, low GI diets have favorable effects on obesity-related sicknesses such as type 2 diabetes [14,15]. The consumer's growing interest in healthier and tastier foods makes the food industry develop new bakery products [16]. Wholegrain foods are essential sources of dietary fiber and their ingestion has been associated with the prevention of chronic diseases due to their bioactive properties and health benefits [17,18]. In this sense, the aforementioned report also recommends the adoption of fiscal measures, such as a tax increase on certain food products and beverages that are rich in trans fatty acids, saturated fats, free sugars and/or salt, since an increase in the price of these products results in a decrease in their consumption. Nevertheless, for the food industry, and specifically the bakery sector, reducing the content of rapidly absorbed sugars along with a reduction in trans fatty acids and saturated fats is a great challenge if market share is to be maintained without breaking away from global and European policies.

Baking is the process that transforms dough in bakery products with exceptional sensorial features. Therefore, the aspect, color of the surface, and flavor of bakery products are the major qualities evaluated by consumers [19]. The bakery sector accounted for $10.7 \%$ of the total turnover of the food and drink industry in 2012. The sector encompasses more than 150,000 companies, representing $54 \%$ of the total number of firms in the drink and food industry [20]. Cakes or muffins, as well as cookies, are products consumed by all levels of society, due to their "ready to eat" format, their accessibility in different varieties, and their reasonable cost. However, the health benefits of these or other bakery products are questionable. Hence, its reformulation-by modifying the type of fats and carbohydrates occurring in them-would undoubtedly contribute to improving the quality of the product, and therefore the diet of its consumers; this also reduces the risk of cardiovascular diseases, as well as the appearance of dental caries or problems associated with obesity [21].

In view of the above, the purpose of the present work is to review the most recent studies dealing with the nutritional improvement of bakery products, carried out by replacing less healthy ingredients such as fats or sugars. Additionally, other papers related to the substitution of whey and/or egg proteins have also been mentioned, given the growing interest in products without this type of protein (intolerance problems).

\section{Different Carbohydrates (Sweeteners) Used in the Bakery}

Low-sugar or low-calorie labels are a top-ranked market trend for the bakery sector, mainly due to the fact that the overconsumption of sweets contributes to increasing obesity among children and adults, as well as other health problems. In this sense, the replacement of sugar with other natural sweeteners is a clear attempt to achieve a healthier lifestyle and has a major influence on the proposals of the bakery industry in terms of the development of innovative products. The market aims at removing the unhealthy ingredients in formulations, particularly sugars, but pays attention to customer satisfaction. Baked goods manufacturers are currently utilizing intense as well as high-volume artificial sweeteners as conventional sugar replacements. Nevertheless, the possibility of employing alternative natural sweeteners, such as Stevia, oligofructose, and isomaltulose, is now opening up, with the advantage of 
their providing some healthy benefits. In this section, we try to present the most recent and relevant contributions in this field, which are summarized in Table 1.

Table 1. Major sugar replacers used in bakery products.

\begin{tabular}{|c|c|c|c|c|}
\hline Bakery Product (s) & $\begin{array}{l}\text { Substance (s) } \\
\text { Proposed }\end{array}$ & Substitution Level & Remarks & Reference \\
\hline $\begin{array}{l}\text { Sunflower butter } \\
\text { cookies }\end{array}$ & $\begin{array}{l}\text { Different } \\
\text { sweeteners }\end{array}$ & $\begin{array}{l}2 \%(w / v) \text { concentration in all } \\
\text { instances (maple syrup, xylitol, } \\
\text { corn syrup, agave } \\
\text { syrup, honey) }\end{array}$ & $\begin{array}{l}\text { Influence of several sweeteners } \\
\text { on greening of sunflower } \\
\text { butter cookies }\end{array}$ & [22] \\
\hline Biscuits & $\begin{array}{l}\text { Low-calorie } \\
\text { sweeteners and } \\
\text { oligofructose }\end{array}$ & $\begin{array}{c}100 \% \text { oligofructose } \\
70 \% \text { maltitol }-30 \% \text { stevia }\end{array}$ & $\begin{array}{c}\text { New biscuit formulations using } \\
\text { low-calorie sweeteners } \\
\text { Quality effect of sugar }\end{array}$ & [16] \\
\hline Muffins & Steviol glycosides & $25 \%$ steviol sweetener & $\begin{array}{l}\text { replacement by } \\
\text { steviol glycosides }\end{array}$ & [23] \\
\hline Muffins & Steviol glycosides & $50 \%$ stevianna or $50 \%$ inulin & $\begin{array}{l}\text { The use of steviol glycosides as } \\
\text { partial a replacement for sucrose } \\
\text { Study of the properties of }\end{array}$ & [24] \\
\hline Different types & $\begin{array}{c}\text { Functional } \\
\text { oligosaccharides }\end{array}$ & & $\begin{array}{l}\text { Study of the properties of } \\
\text { different functional } \\
\text { oligosaccharides as potential } \\
\text { sucrose replacers }\end{array}$ & [25] \\
\hline $\begin{array}{l}\text { Baked snack from } \\
\text { green apples }\end{array}$ & $\begin{array}{l}\text { Isomalt, } \\
\text { maltodextrin }\end{array}$ & $\begin{array}{l}30 \%(w / v) \text { isomalt and } 30 \% \\
(w / v) \text { maltodextrin }\end{array}$ & $\begin{array}{c}\text { The effect of using alternative } \\
\text { noncariogenic } \\
\text { nutritive sweeteners }\end{array}$ & [26] \\
\hline
\end{tabular}

In a very comprehensive work, Struck et al. [27] summarize the state-of-the-art in the use of both natural and artificial high-intensity sweeteners, as well as fructans and polyols (as bulking agents) instead of traditional sugars in sweet baked products and their effects on the characteristics of these goods. The authors point out that this process can be a challenging issue, since it has both advantages and drawbacks. Sucrose as a main component in sweet bakery products provides sweetness but also contributes to numerous processing and product characteristics; on the other hand, intense sweeteners-although their sweetness clearly exceeds that of sucrose-do not contribute significantly to the body of the product, whereas the substitution of sucrose by bulking sweeteners may give rise to products with a similar body but a lack of flavor and/or taste.

Another interesting review was performed by Ghosh and Sudha [28]. This paper focuses on some recent studies performed on sucrose replacement with polyols in baked goods. Polyols are a group of reduced-calorie sweeteners, and can be considered as natural and nutritive sweeteners. In fact, they are a group of low-digestible carbohydrates which can be used instead of sucrose as sweeteners and also as bulking agents, since their sweetness is slightly lower than that of sucrose. They are present naturally in foods and come from plant products such as berries and fruits. They are available in syrups as well as in solid crystalline form and provide the baker with a versatile range of ingredients to increase the available portfolio of products.

High-intensity sweeteners also include steviol glycosides. They are natural non-caloric substances extracted from Stevia rebaudiana Bertoni leaves which are increasingly used as sweeteners for a range of foodstuffs. In another interesting contribution, Karp et al. [23] tried to evaluate the effect of substituting sucrose with steviol glycosides on the quality properties of baked goods, such as muffins. Different parameters such as texture, color, and browning index were analyzed, with a sensory analysis also carried out. According to the study, a $25 \%$ addition of steviol sweetener (instead of sucrose) was the most suitable modification of the conventional formulation. The resulting muffins turned out to have a higher sensory attractiveness, as well as health-promoting qualities. On the other hand, it was also observed that a reduction in sucrose in excess of $50 \%$ negatively affected the quality of muffins and their sensory characteristics.

Zahn et al. [24] studied the possibility of utilizing steviol glycosides for the partial substitution of sucrose in bakery products. As an example, muffins were baked with an iso-sweet amount of rebaudioside A along with several fibers replacing $30 \%$ of sucrose. Color, texture and chemical analyses 
of the resulting products were performed, and their sensory profile was also evaluated. The results provided by a multivariate analysis of both instrumental and sensory data clearly show that a mixture of rebaudioside A with either polydextrose or inulin gives rise to products with similar features to those of a reference. These replacement substances significantly reduced energy and increased fiber content. The employment of apple fiber or wheat bran as a bulk replacer for sucrose resulted in products with a different crumb color and a wholemeal off-taste; nevertheless, partial sucrose replacement by oat, pea or wheat fiber, cellulose or maltodextrin resulted in an increased crumbliness and reduced elasticity.

Erythritol is a sugar alcohol (polyol) occurring naturally in some fruit and fermented foods. It is $60 \%-70 \%$ as sweet as sucrose yet it is almost noncaloric, hence its increasing importance within the food industry. Erythritol is widely used as sweetener in low-calorie bakery products and candies. Nevertheless, its production (unlike that of other polyols) is a challenging issue, since it cannot be chemically synthesized in a commercially worthwhile way; therefore, current research efforts are trying to improve both productivity and yield. A short review by Regnat, Mach, and Mach-Aigner [29] gives an overview of the attempts to improve erythritol production, as well as their development over time.

It is well known that the use of prebiotics has positive effects in stimulating a healthy intestinal tract. The human gut is unable to digest them, so, while they taste sweet, they are calorie free; that is why naturally sweet prebiotics can replace high-calorie sugars in food and drink products. On the other hand, the thermal stability of the product is sometimes improved, along with other textural, sensory, and physiological benefits. A comprehensive paper by Singla and Chakkaravarthi [30] provides an overview of the various prebiotics available from different sources and their applications in a great variety of sectors of the food industry, most notably bakery and confectionary sectors. The effects observed as a consequence of the addition of several prebiotics are also commented on. From this article, it can be inferred that the research in this field opens up new opportunities for the development of a range of natural sweeteners, which can be utilized to replace sugar in, for example, bakery products.

Liang and Were [22] examined the impact of several liquid sweeteners (including syrups and honey) and relative humidity on the chlorogenic acid-induced greening of sunflower butter cookies, which takes place under alkaline conditions. Doughs had a similar initial $\mathrm{pH}$ (7.5-7.7) which increased to 8.4-9.1 after baking. The results obtained showed that cookies enhanced with maple syrup had the highest moisture and greening, corresponding with the lowest free chlorogenic acid. According to the authors, a satisfactory correlation $(\mathrm{r}=0.91)$ was obtained between the $\%$ greening and the chlorogenic-lysine adduct content. The results of this work show that undesirable greening can be inhibited by the use of an alternative liquid sweetener.

The research work of Martínez-Saez et al. [16] evaluated the utilization of spent coffee grounds (SCG) from instant coffee as a food ingredient and its application in bakery goods. Different evaluation assays of SCG were conducted; the results obtained showed that SCG $(4 \% w / w)$ are a natural source of low glycaemic sugars, resistant to thermal food processing and the digestion process, and completely safe. Therefore, the authors incorporated SCG in biscuit formulations as a novelty. Low-calorie sweeteners and oligofructose were also included in the food formulations, and corresponding sensory tests of the biscuits were performed. This work resulted in innovative biscuits in accordance with consumers' preferences, being straightforward, with high nutritional and sensorial quality and the potential to reduce the risk of diabetes and obesity.

There is also growing interest in low-intensity sweeteners such as oligosaccharides, partly due to their prebiotic status; that is why oligosaccharides from different sources (fungi, algae, bacteria, and others) have been widely utilized as food ingredients. The non-digestible oligosaccharides have played different roles as sweeteners, dietary fiber, or weight-controlling agents in confectioneries. On the other hand, functional oligosaccharides have turned out to be of great utility in dental caries' prevention, as well as in the regulation of blood glucose in diabetics. Considering the importance of these compounds, Patel and Goyal [25] discuss their natural sources, types, and physiological properties, and describe recent synthesis, purification and analysis methods. Promising recent developments in this area are also remarked on, to facilitate their further exploitation. 
The purpose of Tavera-Quiroz et al. [26] was to develop a crispy snack (baked snack from green apples) with the addition of isomalt and maltodextrin. Isomalt (a reduction product of isomaltulose) is often utilized in bakery goods as a noncariogenic nutritive sweetener. Its physical, chemical, and sensory properties were then assessed, followed by an evaluation of its stability during storage and after being conditioned at different relative humidities. The use of isomalt had a protective effect on the apple tissue at high temperatures and also preserved the ascorbic acid (E-300) added along the baking process. The isotherms obtained reflected a resistant behavior pattern in regions with low water activity (aw), but, in the case of aw $>0.7$, the moisture content increased drastically.

Finally, Rodríguez, Magan and Medina [11] compared the influence of (a) three different Stevia-based sugar replacers (named S1-S3 by the authors), (b) sucrose alone, and (c) a combination of sucrose and S1 on: (1) humectant properties, (2) relative colonization rates of sponge cake slices at 0.90 aw by some major strains at 20 and $25^{\circ} \mathrm{C}$ and (3) shelf-life periods in days prior to visible growth. From the results obtained, it can be concluded that $\mathrm{S1}$, sucrose, and their combination were able to reach aw levels close to those of glucose and glycerol mixtures, whereas neither S2 nor S3 significantly reduced water activity levels. This work also performs a comprehensive study of the growth that occurred in all treated sponge cake slices at both temperatures. Finally, the authors conclude that care must be taken when substituting sucrose with low-calorie sugar replacers based on Stevia glycosides. They point out that different products may have variable humectant properties and bulking agents which could decrease the potential shelf-life of intermediate moisture confectionery goods.

\section{Components to Replace Fats}

Oils and fats added to bakery products play a very important role in their formulation. During the mixing and beating of the ingredients, fat (due to its surface-active properties) contributes to the incorporating and stabilizing of gas bubbles in the dough, and also prevents the excessive development of gluten proteins. Moreover, in the baked product, fats improve the final texture and increase its volume [31]. On the whole, butter, margarine, lard, cream, hydrogenated coconut oil, and sunseed or olive oils are used in these products; the proportion of the liquid and solid phase in each one of them determines the ability to stabilize gas bubbles [32].

Fats may represent up to $20 \%$ or $35 \%$ of the product, those containing a high level of saturated fatty acids (SFA, related to cardiovascular diseases and obesity) being common. On the other hand, trans fats are usually added to bakery products; these types of fats are obtained from a hydrogenation process of vegetable fats in such a way that they have similar structural properties to those of animal fats (essentially, a higher melting point). This process converts a liquid oil into a solid paste that improves the texture of many foodstuffs. Nevertheless, trans fatty acids are also related to the risk of heart diseases, since they increase low-density lipoprotein (LDL) cholesterol levels and reduce those of high-density lipoprotein (HDL); that is why their consumption must be kept low [33].

Due to these reasons, a better quality of the type of fat consumed is of paramount importance. Over the course of time, different ingredients have been utilized to replace fat in foods (Table 2), be they of lipid or protein nature, or even from carbohydrates [34]. 
Table 2. Different proposals for fat replacements in selected bakery products.

\begin{tabular}{|c|c|c|c|c|}
\hline Fat Replacer & Products & Substitution Level & Results & References \\
\hline High oleic sunflower oil & $\begin{array}{c}\text { Cookies } \\
\text { Croissants } \\
\text { Spanish muffins } \\
\text { Spanish sponge cake }\end{array}$ & $\begin{array}{l}100 \% \text { margarine } \\
20 \% \text { margarine } \\
100 \% \text { sunflower oil } \\
100 \% \text { sunflower oil }\end{array}$ & $\begin{array}{c}\text { Better nutritional properties } \\
\text { Only cookies maintained } \\
\text { sensory acceptability and purchase intention }\end{array}$ & [35] \\
\hline $\begin{array}{l}\text { Garden cress (Lepidium sativum) } \\
\text { seed oil or Microencapsulated } \\
\text { garden cress oil powder }\end{array}$ & Biscuits & $25 \%$ bakery shortening fat & $\begin{array}{c}\text { Enhanced the nutritional quality of products } \\
\text { with } \alpha \text {-linolenic acid } \\
\text { Increases the shelf-life over storage of biscuits } \\
\text { with alpha-linolenic acid }\end{array}$ & [36] \\
\hline Flax seed (Linum usitatissimum) & Cookies & $\begin{array}{l}\text { Wheat flour with } 0 \%, 5 \%, 10 \%, 15 \% \\
\text { and } 20 \% \text { flax seeds }\end{array}$ & $\begin{array}{l}\text { (ALA) microencapsulated } \\
\text { Beyond 15\% level of recovery growth factor } \\
\text { (RGF) substitution adversely affected } \\
\text { cookies quality } \\
\text { Acceptable quality cookies with omega-3-fatty } \\
\text { acid can be prepared by substituting } 15 \% \text { RGF }\end{array}$ & {$[37]$} \\
\hline Chia (Salvia hispanica L.) flour & Biscuits & $\begin{array}{l}\text { Wheat flour with } 0 \%, 5 \%, 10 \%, 15 \% \\
\text { and } 20 \% \text { chia flour }\end{array}$ & $\begin{array}{l}\text { Nutritionally improved product, with higher } \\
\text { amounts of protein, dietary fiber, } \\
\text { antioxidants and polyunsaturated fatty acids } \\
\text { Increased the formation of acrylamide, }\end{array}$ & {$[38]$} \\
\hline $\begin{array}{l}\text { Whole chia flour (Salvia } \\
\text { hispanica } L . \text {.) and hydrogenated } \\
\text { vegetable fat }\end{array}$ & Pound Cakes & $\begin{array}{l}0-30 \mathrm{~g} \text { chia flour } / 100 \mathrm{~g} \text { flour mixture } \\
\text { and } 12-20 \mathrm{~g} \text { hydrogenated vegetable } \\
\text { fat/100 } \mathrm{g} \text { flour mixture }\end{array}$ & $\begin{array}{l}\text { hydroxymethylfurfural (HMF) and furfural } \\
\text { and promoters such as methylglyoxal } \\
\text { The best technological results were in cakes } \\
\text { containing up to } 15 \mathrm{~g} \text { whole chia flour } \\
\text { (WCF)/100 g flour mixture and from } 16 \text { to } 20 \mathrm{~g} \\
\text { hydrogenated vegetable fat (HVF)/100 g } \\
\text { flour mixture } \\
\text { Nutritionally enhanced, mainly in relation to } \\
\text { the omega-3 content } \\
\text { and omega-6/omega-3 ratio }\end{array}$ & [39] \\
\hline
\end{tabular}


Table 2. Cont

\begin{tabular}{|c|c|c|c|c|}
\hline Fat Replacer & Products & Substitution Level & Results & References \\
\hline Chia seeds and chia flour & Bread & $\begin{array}{l}0-20 \mathrm{~g} \text { chia flour } / 100 \mathrm{~g} \text { wheat flour } \\
\text { and } 0-3 \mathrm{~g} \text { hydrogenated vegetable } \\
\text { fat } / 100 \mathrm{~g} \text { wheat flour; } 2-20 \mathrm{~g} \text { chia } \\
\text { seeds } / 100 \text { wheat flour and } 0-3 \mathrm{~g} \\
\text { hydrogenated vegetable fat } / 100 \mathrm{~g}\end{array}$ & $\begin{array}{c}\text { Increased the ratio PUFA:SFA from } 1.01 \\
\text { (control bread) to } 3.1 \text { (chia flour) and } 3.9 \\
\text { (chia seeds) } \\
\text { Decrease in the specific volume } \\
\text { In sensory evaluation, high levels of } \\
\text { acceptability and purchase plans }\end{array}$ & [40] \\
\hline Chia mucilage gel & Cakes & $\begin{array}{l}\text { wheat flour } \\
25,50,75 \text { and } 100 \mathrm{~g} / 100 \mathrm{~g} \text { of vegetable } \\
\text { fat by chia mucilage gel (CMG) }\end{array}$ & $\begin{array}{c}\text { Formulations with up to } 25 / 100 \mathrm{~g} \text { of fat } \\
\text { substitution presented similar technological } \\
\text { characteristics to the control } \\
\text { Levels superior to } 25 / 100 \mathrm{~g} \text { of fat substitution } \\
\text { affects negatively color and texture }\end{array}$ & [41] \\
\hline & & & $\begin{array}{l}\text { Decrease ratio of n- } 6 \text { to } n-3 \text { fatty acids from } \\
215.7 \text { (control) to } 13.2 \text { ( } 75 \% \text { oil substitution) }\end{array}$ & \\
\hline Chia (Salvia hispanica L.) gel & Cakes & $25 \%, 50 \%$ and $75 \%$ of oil & $\begin{array}{c}\text { Cake weight was not statistically different from } \\
\text { control at any substitution level } \\
\text { Cake volume decrease with substitution } \\
\text { increase above } 50 \%\end{array}$ & {$[42]$} \\
\hline Chia mucilage (CM) dryed & Bread and chocolate cakes & $\begin{array}{c}25 \%, 50 \%, 75 \% \text { and } 100 \% \text { of } \\
\text { vegetable fat }\end{array}$ & $\begin{array}{l}\text { Significant effect when replacing above } 50 \% \text { for } \\
\text { acceptability, color, texture and taste } \\
\text { Reduction in caloric value } \\
\text { The bread prepared with } 75 \% \text { showed a higher } \\
\text { acceptability and greater purchase intent } \\
\text { For chocolate cakes, chia mucilage can replace } \\
\text { up to } 50 \% \text { of fat without affecting the } \\
\text { technological and physical characteristics }\end{array}$ & [43] \\
\hline Green banana puree & Pound cakes & $0 \%-100 \%$ of fat & $\begin{array}{c}\text { Increased firmness, springiness, luminosity, } \\
\text { color saturation and hue angle in the crust of } \\
\text { the product. The best results were obtained } \\
\text { with } 25 \% \text { replacement }\end{array}$ & [44] \\
\hline
\end{tabular}


Table 2. Cont.

\begin{tabular}{|c|c|c|c|c|}
\hline Fat Replacer & Products & Substitution Level & Results & References \\
\hline $\begin{array}{l}\text { Oil/gel systems: sunflower or } \\
\text { olive }(47 \%) / H P M C \text { or xanthan } \\
\text { gum }(2 \%)\end{array}$ & Biscuits & $100 \%$ of shortening at $18 \%$ fat & $\begin{array}{l}\text { The biscuits prepared with either olive oil or } \\
\text { sunflower oil and xanthan gum differed the } \\
\text { most from the biscuit control. The biscuits } \\
\text { formulated with either olive oil or sunflower } \\
\text { oil and HPMC had the closest sensory } \\
\text { properties to the shortening biscuits. }\end{array}$ & [45] \\
\hline Maltodextrin and guar gum & Biscuits & $\begin{array}{l}\text { Formulations with fat } 10.5 \%-24.5 \% \text {, } \\
\text { maltodextrin } 10.4 \%-24 \% \text { and guar } \\
\text { gum } 0.1 \%-0.5 \%\end{array}$ & $\begin{array}{l}\text { Optimized product has } 62.5 \% \text { replacement of } \\
\text { fat with maltodextrin and guar gum }\end{array}$ & [46] \\
\hline $\begin{array}{l}\text { Emulsions sunflower oil }(51 \%) \text {, } \\
\text { hydroxipropilme-thylcellulose } \\
\qquad \begin{array}{c}\left(4 \text { or } 250 \mathrm{~Pa} \mathrm{~s}^{-1}\right)(2 \%) \\
\text { water }(47 \%)\end{array}\end{array}$ & Muffins & & $\begin{array}{l}\text { The emulsion muffins were significantly } \\
\text { harder and had a lower sensory acceptability }\end{array}$ & [47] \\
\hline $\begin{array}{l}\text { Inulin, hydroxypropyl } \\
\text { methylcellulose and } \\
\text { maltodextrin }\end{array}$ & Pea cracker & $\begin{array}{l}0 \%, 25 \%, 50 \%, 75 \% \text { and } 100 \% \text { of } \\
\text { canola oil }\end{array}$ & $\begin{array}{l}\text { Snack hardness increase and browning } \\
\text { decrease as fat replacement level increased } \\
\text { Snacks are accepted by consumers with 75\% }\end{array}$ & [48] \\
\hline $\begin{array}{l}\text { Corn fiber, maltodextrin and } \\
\text { lupine extract }\end{array}$ & Biscuits & $30 \%$ or $40 \%$ fat & $\begin{array}{c}\text { Increased moisture content after baking; } \\
\text { volume increase was lower and the firmness } \\
\text { increased drastically. } \\
\text { All changes highest when lupine extract } \\
\text { was used }\end{array}$ & [49] \\
\hline $\begin{array}{l}\text { Polydextrose (PD) } \\
\text { and Simplesse }^{\circledR}\end{array}$ & Biscuits & $10 \%-40 \%$ & $\begin{array}{c}\text { PD is more suitable than Simplesse }{ }^{\circledR} \\
\text { PD can be used up to } 30 \% \text { to partially replace } \\
\text { the fat without significantly affecting the } \\
\text { sensorial properties } \\
\text { Reduction of } 15.98 \% \text { of energy and } 30 \% \text { less } \\
\text { fat content }\end{array}$ & [50] \\
\hline
\end{tabular}


Table 2. Cont.

\begin{tabular}{|c|c|c|c|c|}
\hline Fat Replacer & Products & Substitution Level & Results & References \\
\hline Maltodextrin & Biscuits & $\begin{array}{l}\text { Ratio maltodextrin:bakery fat }(0: 42 \text { to } \\
\text { 35:7) }\end{array}$ & $\begin{array}{c}\text { Biscuits with } 20 \text { g replacement got the highest } \\
\text { sensory score }\end{array}$ & [51] \\
\hline $\begin{array}{l}\text { N-Dulge (tapioca dextrin and } \\
\text { tapioca starch) }\end{array}$ & Biscuits & $10 \%$ and $20 \%$ of shortening & $\begin{array}{l}\text { Increase hard and crumb with fat decreased by } \\
10 \% \text { shortening replacement achieved samples } \\
\text { with good acceptability }\end{array}$ & [52] \\
\hline Inulin & Short-dough biscuits & $\begin{array}{c}74.1 \%, 64.8 \% \text { and } 55.4 \% \text { margarine } \\
\text { and } 0.9 \% \text { and } 18.3 \%\end{array}$ & & [53] \\
\hline $\begin{array}{c}\text { Emulsion filled gel (EFG) based } \\
\text { on inulin and extra virgin } \\
\text { olive oil }\end{array}$ & Shortbread cookies & $\begin{array}{c}50 \% \text { and } 100 \% \text { of butter replaced } \\
\text { by EFG }\end{array}$ & $\begin{array}{l}\text { Cookies with EFG had thinner pore walls. } \\
\text { Cookies with } 50 \% \text { EFG showed similar } \\
\text { microstructure and fracture properties to } \\
\text { control and were well accepted by consumers }\end{array}$ & [54] \\
\hline
\end{tabular}


The use of lipidic substitutes (often containing omega 3) involves modifying the ratio SFA:MUFA:PUFA (MUFA = monoinsaturated fatty acids; PUFA $=$ polyinsaturated fatty acids). Sunseed oil, commonly utilized in sponges and muffins, has a 10\%:29\%:61\% ratio, whereas that of margarine in cookies and croissants is 50\%:33\%:17\% [35]. These authors also tried to increase the MUFA content and reduce the level of SFA; for this purpose, they evaluated the replacement of margarine and sunseed oil by oleic-rich sunseed oil in several products (cookies, croissants, muffins, and sponges). They found that these new formulations not only improved the lipidic profile but also reduced the total amount of fat, and thus their caloric value. Nevertheless, only cookies received a good sensorial score.

In this way, the change in the lipidic profile of bakery products using seed oils can be a good strategy to increase their nutritional profile. However, the addition of seed oils from flax (Linum usitatissimum), camelina (Camelina sativa), or garden cress (Lepidium sativum), with a high content of omega- 3 fatty acids (mainly $\alpha$-linoleic acid), gave rise to high oxidation ratios during the storage of sponges, unless microencapsulation techniques were used [36,55,56]. Rajiv et al. [37] point out the possibility of replacing up to $15 \%$ wheat flour with flax seeds with no significant changes in the peroxide value, during cookies' storage in metallized polyester pouches at ambient conditions.

Chia seeds (Salvia hispanica L.) with a high oil content (30\%-40\%), mainly omega-3 (linolenic acid, $54 \%-67 \%$ ) and omega-6 (linoleic acid, $12 \%-21 \%)$, as well as in protein $(15 \%-25 \%)$ and fiber $(18 \%-30 \%)$, aim at improving the nutritional profile of bakery products [43,57]. In this sense, many authors have used this seed in different formats.

According to Mesías et al. [38], the addition of ca. 10\% chia flour to sponges improved the nutritional value of the product, but also the levels of acrylamide, hydroxy methyl furfural, and furfural; however, it reduces the shelf life of the product by accelerating the oxidation of lipids. Pizarro et al. [39] studied the replacement of wheat flour by chia flour (up to 30\%) in the preparation of sponges, which resulted in a decrease in both specific volume and color parameters with increasing chia flour concentration. These negative effects were countered by the addition of hydrogenated vegetable fats, with an optimum formulation being obtained by $15 \mathrm{~g}$ chia flour and $20 \mathrm{~g}$ hydrogenated fat (total flour $=100 \mathrm{~g}$ ). Coelho and de las Mercedes Salas-Mellado [40] optimized a bread formulation using chia flour or seeds, with a PUFA:SFA ratio of 3.1 and 3.9 (control bread had a ratio of 1.01).

Chia mucilage, obtained from seed hydration, can also act as fat replacer, thanks to its high water-absorption capacity and increase in dough viscosity [41]. The substitution of either $25 \%$ of fat in sponges [58] or 50\% in sponges and biscuits [42,43], by dehydrated chia mucilage (by means of hot air or lyophilization) does not significantly modify the organoleptic characteristics of sponges, whereas the lipid profile improves.

Some researchers have studied the influence—on dough and final product properties—of the replacement of fats traditionally used in bakery wares by hemicellulose-rich ingredients, such as green banana puree (GBP) [44]. The substitution of butter in different proportions (evaluated through sensory attributes) gave rise to changes in color, texture, odor, and taste of the sponges. It was feasible to substitute $25 \%$ of fat with GBP in pound cakes, as well as to reduce $20 \%-40 \%$ of sugar in low-fat cakes with GBP, with very little impact on acceptance and sensory characteristics. By-products of the fruit industry (rich in bioactive components) have also been studied as fat replacements, for instance, berry pomace in sponge cakes (30\% substitution) [59], avocado purée in muffins [60] (50\% substitution), and okra gum [61] (100\% substitution) in chocolate bar cookies; products with a good sensorial acceptance were obtained in these cases.

Several authors have evaluated the reduction in the fat content in sponges or muffins by using different replacers based on carbohydrates, such as xanthan gum [45], guar gum [46], hydroxypropyl methylcellulose [45,47,48] maltodextrins [46,48-51], dextrins [52], or inulin [53]. In general, this substitution affects the textural properties of the baked products, them being harder, and thus they have lower acceptance levels than control products. 


\section{Substitution of Proteins}

Eggs are used in baking for several important functional properties, such as binding, leavening, tenderizing, volume, texture, stabilization, emulsification, foaming, coagulation, flavor, color, and food/nutritional value [62]. Nevertheless, eggs are considered one of the most allergenic foods, and that is why their possible substitution in bakery products has been extensively researched. Most commonly used commercial egg replacers use whey protein isolates, soy ingredients, wheat gluten, and different types of gums as the main functional components in the ingredient mixture in order to obtain specific properties in bakery products [62].

In addition to egg protein, most of the protein in bakery products comes from flour, which forms an elastic dough along with the water. Gluten proteins, mainly gliadin and gluteine, are also highly allergenic. Thus, gluten replacement in bakery products is a fundamental technological challenge, due to its essential structural binding properties. In recent years, numerous researchers have been working on the development of gluten-free products by the substitution of wheat floor with different gluten-free cereal flours such as those from rice [63-65], acorn [66,67], soybean [68], sorghum [69-71] or mixtures [72-74]. Other studies have evaluated wheat flour replacement by pseudo-cereals such as amaranth [75-78], quinoa [79-81], buckwheat [78,82-84] or legume flours [85-89].

On the other hand, when using gluten-free ingredients, substances that have the properties of gluten are frequently added as isolated proteins (from egg, legumes, or dairy products), hydrocolloids (alginate, guar and xanthan gums, carrageenan, carboxymethyl cellulose, hydroxypropyl methylcellulose), emulsifiers, or enzymes (proteases, transglutaminase, glucose oxidase, cyclodextrin glycosyl transferases and laccase) $[86,89,90]$. Table 3 summarizes some of the major contributions in the last few years in this field. 
Table 3. Selected alternatives for protein replacements in bakery products.

\begin{tabular}{|c|c|c|c|c|}
\hline Protein Replaced/Alternative & Products & Substitution Level & Results & References \\
\hline $\begin{array}{l}\text { Whole egg/three commercial } \\
\text { egg replacers (R1, R2 and R3) }\end{array}$ & Muffins & - 25\% dry whole egg $+75 \%$ R1 & $\begin{array}{l}\text { At } 100 \% \text { replacement, none of the commercial } \\
\text { egg replacers produced acceptable quality }\end{array}$ & [62] \\
\hline Wheat flour/rice, corn, soy flour & Gluten-free bread & $\begin{array}{c}-25 \% \text { dry whole egg }+15 \% \text { R2 } \\
-50 \% \text { dry whole egg }+50 \% \text { R3 } \\
\text { Rice }(100) \\
\text { Rice/Corn }(50: 50) \\
\text { Rice/Soy }(90: 10) \\
\text { Rice/Soy }(80: 20) \\
\text { Corn/Soy }(90: 10) \\
\text { Corn/Soy }(80: 20) \\
\text { Rice/Corn/Soy }(45: 45: 10) \\
\text { Rice/Corn/Soy }(40: 40: 20)\end{array}$ & $\begin{array}{l}\text { muffins. Partial replacement of egg changed } \\
\text { moisture retention, bulk volume, color, } \\
\text { texture and flavor. Some of these differences, } \\
\text { were not detected by the sensory panelists } \\
\text { Breads made with rice, corn, and soy flours } \\
\text { showed the best quality attributes: high specific } \\
\text { volume, good crumb appearance, soft texture, } \\
\text { and low staling rate. The addition of soy caused } \\
\text { crumb softening and retarded bread staling }\end{array}$ & {$[63]$} \\
\hline $\begin{array}{l}\text { Wheat flour/white, brown and } \\
\text { germinated brown rice (GBR) }\end{array}$ & Sugar-snap cookies & $\begin{array}{c}30 \%, 50 \%, 70 \% \text { and } 100 \% \text { of } \\
\text { wheat flour }\end{array}$ & $\begin{array}{l}\text { All cookies containing rice flours required } \\
\text { significantly less force to compress than the } \\
\text { wheat flour cookies. Softening effect was } \\
\text { increased as the level of rice flour substitution } \\
\text { increased. Cookies made with the GBR flour } \\
\text { displayed inferior physical characteristics } \\
\text { compared to those with wheat flour. }\end{array}$ & [64] \\
\hline $\begin{array}{l}\text { Wheat flour/hydrothermal } \\
\text { treatment of rice or corn flours } \\
\text { and field bean }\end{array}$ & Gluten-free bread & $\begin{array}{l}100 \% \text { of wheat flour by ratio } 2 / 1 \\
(w / w) \text { cereal/field bean semolina }\end{array}$ & $\begin{array}{l}\text { Hydrothermal treatment of rice or corn flours } \\
\text { increases the specific volume of breads and H/W } \\
\text { ratio and decreases the hardness and chewiness }\end{array}$ & [65] \\
\hline $\begin{array}{l}\text { Wheat flour/rice flour or corn } \\
\text { starch with acorn meal }\end{array}$ & gluten-free bread & $\begin{array}{l}100 \% \text { of wheat flour by rice flour } \\
\text { and corn starch }(1: 1) \text { with acorn } \\
\text { meal addition }(5 \%, 15 \%, 25 \%)\end{array}$ & $\begin{array}{l}\text { Acorn-supplemented gluten free breads better } \\
\text { met sensory preference in terms of color and } \\
\text { nutritionally improved in terms of total } \\
\text { phenolics. The specific volume of breads } \\
\text { significantly decreased with increasing acorn } \\
\text { addition, while crumb hardness increased }\end{array}$ & [66] \\
\hline $\begin{array}{l}\text { Wheat flour/acorn flour } \\
\text { in biscuits }\end{array}$ & & $\begin{array}{l}30 \text { and } 60 \mathrm{~g}, 100 \mathrm{~g}^{-1} \text { on wheat } \\
\text { flour basis. }\end{array}$ & $\begin{array}{l}\text { Biscuits with acorn showed a higher content of } \\
\text { phenolics, antioxidant activity and oxidative } \\
\text { stability than control biscuits. They were also } \\
\text { darker, larger, more voluminous and more } \\
\text { friable than control biscuits. }\end{array}$ & {$[67]$} \\
\hline
\end{tabular}


Table 3. Cont

\begin{tabular}{|c|c|c|c|c|}
\hline Protein Replaced/Alternative & Products & Substitution Level & Results & References \\
\hline $\begin{array}{l}\text { Wheat flour/cornstarch and } \\
\text { white sorghum }\end{array}$ & Gluten-free bread & $\begin{array}{l}100 \% \text { of wheat flour by different } \\
\text { cornstarch/sorghum flour ratio }\end{array}$ & $\begin{array}{l}\text { The optimized recipe was } 0.55 \\
\text { cornstarch/sorghum flour ratio }\end{array}$ & [69] \\
\hline Wheat flour/sorghum flour & Gluten-free bread and cake & $\begin{array}{l}100 \% \text { of wheat flour by dry heat } \\
\text { sorghum flour at } \\
\text { two temperatures }\end{array}$ & $\begin{array}{l}\text { Heating the flour at } 125^{\circ} \mathrm{C} \text { for } 30 \text { min produced } \\
\text { bread and cakes with the highest specific volume } \\
\text { and the most cells per slice area. Cake and bread } \\
\text { made from this heat treatment were more } \\
\text { acceptable than the controls in consumer testing }\end{array}$ & {$[70]$} \\
\hline Wheat flour/sorghum flour & Gluten free biscuits & $\begin{array}{l}100 \% \text { of wheat flour by sorghum } \\
\text { flour of different particle sizes }\end{array}$ & $\begin{array}{l}\text { The hardness was higher in biscuits prepared } \\
\text { from flour of particle size } 152,104 \text { and } 75 \mu \mathrm{m} \\
\text { compared to } 251 \mu \mathrm{m} \text { and } 180 \mu \mathrm{m} . \mathrm{L}^{*} \text { and } \mathrm{b}^{*} \\
\text { parameters were higher in hammer-milled flour } \\
\text { and } \mathrm{a}^{*} \text { and whiteness index were higher in } \\
\text { traditionally milled flour. Acceptability was } \\
\text { higher in biscuits prepared from the traditionally } \\
\text { milled flour of particle sizes. }\end{array}$ & {$[71]$} \\
\hline $\begin{array}{l}\text { Wheat flour/amaranth, } \\
\text { buckwheat, corn, chickpea, } \\
\text { millet and quinoa flour (MF) } \\
\text { and rice flour (RF) }\end{array}$ & Gluten-free bread & $\begin{array}{l}100 \% \text { of wheat flour by ratio } \\
\text { FM:RF of } 1: 1,3: 7 \text { and } 7: 3\end{array}$ & $\begin{array}{l}\text { The most positive impact was with the presence } \\
\text { of buckwheat flour. Millet and corn flour } \\
\text { negatively impacted rice dough behavior, } \\
\text { resulting in bread of unacceptable quality }\end{array}$ & [72] \\
\hline $\begin{array}{l}\text { Wheat flour/rice, maize, } \\
\text { sorghum and pearl millet flour }\end{array}$ & Cookies & $\begin{array}{l}100 \% \text { of wheat flour by flour } \\
\text { combinations (50:50) }\end{array}$ & $\begin{array}{l}\text { All the blends of flour significantly improved } \\
\text { pasting qualities, functional properties, } \\
\text { sensory qualities and nutritional values }\end{array}$ & [73] \\
\hline $\begin{array}{l}\text { Wheat flour }(\mathrm{W}) / \text { oats }(\mathrm{O}) \text { and } \\
\text { finger millet }(\mathrm{M})\end{array}$ & Cookies & $\begin{array}{l}\text { Ratios O:M:W: 10:10:80, 20:20:60, } \\
\text { 30:30:40 and 40:40:20 }\end{array}$ & $\begin{array}{l}\text { Oat and finger millet flour addition significantly } \\
\text { improved the dietary fiber content, } \\
\text { protein content and crude fat content. }\end{array}$ & [74] \\
\hline Wheat flour/amaranth flour & Cookies & $20 \%, 40 \%, 60 \%, 80 \%$, and $100 \%$ & $\begin{array}{l}\text { Hardness of cookies decreased with the addition } \\
\text { of amaranth flour. Amaranth cookies with up to } \\
60 \% \text { were sensory acceptable }\end{array}$ & [75] \\
\hline
\end{tabular}


Table 3. Cont

\begin{tabular}{|c|c|c|c|c|}
\hline Protein Replaced/Alternative & Products & Substitution Level & Results & References \\
\hline $\begin{array}{l}\text { Wheat flour/raw and } \\
\text { germinated amaranth } \\
\text { grain flour }\end{array}$ & Cookies & $100 \%$ of wheat flour & $\begin{array}{l}\text { Raw amaranth flour cookies showed the highest } \\
\text { spread ratio, followed by germinated amaranth } \\
\text { flour. Germinated amaranth cookies exhibited } \\
\text { highest antioxidant activity and total dietary } \\
\text { fiber. Acceptable quality and improved nutrition } \\
\text { found in gluten-free cookies with germinated } \\
\text { amaranth flour. }\end{array}$ & {$[76]$} \\
\hline $\begin{array}{l}\text { Wheat flour/composite } \\
\text { amaranth-oat flour }\end{array}$ & Cookies & $\begin{array}{l}100 \% \text { of wheat flour by } \\
\text { amaranth flour or ratio } 3: 1 \\
\text { amaranth-oat flour }\end{array}$ & $\begin{array}{l}\text { Amaranth and its composites improved } \\
\text { water-holding capacities. Amaranth-oat cookies } \\
\text { were acceptable in color, flavor and texture with } \\
\text { no significant differences in sensory qualities. } \\
\text { They also had enhanced nutritional value }\end{array}$ & [77] \\
\hline $\begin{array}{l}\text { Whole wheat flour, amaranth } \\
\text { flour and buckwheat } \\
\text { flour/chickpea }\end{array}$ & Cookies & $\begin{array}{c}0 \%, 20 \%, 40 \%, 60 \%, 80 \% \text { and } \\
100 \% \text { of chickpea }\end{array}$ & $\begin{array}{l}\text { Optimal levels of chickpea addition were } \\
20 \%-40 \% \text { in wheat cookies and } 60 \%-80 \% \text { for } \\
\text { amaranth and buckwheat cookies }\end{array}$ & [78] \\
\hline $\begin{array}{l}\text { Wheat flour/quinoa flour, } \\
\text { quinoa flakes and corn starch }\end{array}$ & Cookies & $\begin{array}{l}100 \% \text { of wheat flour by } \\
\text { composite of quinoa flour, } \\
\text { quinoa flakes and corn starch }\end{array}$ & $\begin{array}{l}\text { Optimized formulation: } 30 \% \text { quinoa flour, } \\
25 \% \text { quinoa flakes and } 45 \% \text { corn starch }\end{array}$ & [79] \\
\hline Wheat flour/quinoa flour & Cookies & $\begin{array}{c}\text { Wheat flour by } 10 \%, 20 \% \text { and } \\
30 \% \text { quinoa flour }\end{array}$ & $\begin{array}{c}\text { Partial replacement of wheat flour by quinoa } \\
\text { flour (up to } 30 \% \text { ) increased the nutritional value } \\
\text { of the cookies without changing the } \\
\text { sensory characteristics }\end{array}$ & [81] \\
\hline Wheat flour/buckwheat flour & Cookies & $\begin{array}{c}\text { Wheat flour by } 0 \%, 20 \%, 40 \% \\
60 \%, 80 \% \text { and } 100 \% \\
\text { buckwheat flour }\end{array}$ & $\begin{array}{l}\text { Increased the antioxidant properties of blended } \\
\text { flour and metal chelating properties, } \\
\text { hardness and spread ratio decreased }\end{array}$ & {$[82]$} \\
\hline Rice flour/buckwheat flour & Cookies & $\begin{array}{c}\text { Rice flour by } 10 \%, 20 \% \text { and } 30 \% \\
\text { buckwheat flour }\end{array}$ & $\begin{array}{l}\text { Higher mineral content and total phenolic } \\
\text { content. Cookies containing } 20 \% \text { light } \\
\text { buckwheat flour had the most acceptable } \\
\text { sensory properties }\end{array}$ & [83] \\
\hline $\begin{array}{l}\text { Rice flour/buckwheat flour and } \\
\text { carboxymethyl cellulose }\end{array}$ & Cookies & $\begin{array}{c}\text { Rice flour by } 10 \%, 20 \% \text { and } 30 \% \\
\text { buckwheat flour. Formulation } \\
\text { containing } 20 \% \text { of buckwheat } \\
\text { flour without the addition of } \\
0,69 \% \text { CMC }\end{array}$ & $\begin{array}{l}\text { Addition of CMC increased dough tenacity and } \\
\text { resistance to deformation. Buckwheat addition } \\
\text { decreased hardness and fracturability of cookies, } \\
\text { as well as the overall acceptability }\end{array}$ & {$[84]$} \\
\hline
\end{tabular}


Table 3. Cont

\begin{tabular}{|c|c|c|c|c|}
\hline Protein Replaced/Alternative & Products & Substitution Level & Results & References \\
\hline $\begin{array}{l}\text { Wheat flour/chickpea flour, } \\
\text { pea isolate, carob germ flour or } \\
\text { soya flour }\end{array}$ & Gluten-free bread & $100 \%$ of wheat flour & $\begin{array}{l}\text { Chickpea bread showed the softest crumb, } \\
\text { the best physico-chemical characteristics and, } \\
\text { in general, good sensory properties }\end{array}$ & [85] \\
\hline Wheat flour/jering seed flour & Cookies & $\begin{array}{c}0 \%, 5 \%, 10 \%, 15 \%, 20 \% \text { and } \\
100 \% \text { of wheat flour }\end{array}$ & $\begin{array}{l}\text { Cookies had higher protein, fiber and ash. } \\
\text { Changes in optical properties with jering } \\
\text { addition. Most acceptable sensory quality with } \\
10 \% \text { replacement }\end{array}$ & [86] \\
\hline Wheat flour/lentil flour & Layer and sponge cakes & $50 \%$ and $100 \%$ of wheat flour & $\begin{array}{l}\text { Lentil flours reduced the density of layer-cake } \\
\text { batter but increased the density of sponge-cake } \\
\text { batter. Adding lentil flour reduced layer-cake } \\
\text { volume, symmetry index, cohesiveness and } \\
\text { springiness and increased hardness. In sponge } \\
\text { cakes, substitution of wheat flour with lentil } \\
\text { flour gave rise to harder and less cohesive cakes }\end{array}$ & [89] \\
\hline $\begin{array}{c}\text { Durum wheat and } \\
\text { semolina/Apulian Black } \\
\text { Chickpea wholemeal flour }\end{array}$ & Bread, focaccia and pizza crust & $\begin{array}{l}\text { DW (durum wheat re-milled } \\
\text { semolina) BC (product prepared } \\
\text { by using a composite meal } \\
\text { containing } 60 / 100 \mathrm{~g} \text { of durum } \\
\text { wheat re-milled semolina and } \\
40 / 100 \mathrm{~g} \text { of Apulian black } \\
\text { chickpea wholemeal flour) }\end{array}$ & $\begin{array}{l}\text { Apulian black chickpeas to durum wheat } \\
\text { re-milled semolina caused a decrease in the } \\
\text { bread-making but there was a nutritional } \\
\text { improvement in terms of higher contents of fiber } \\
\text { and proteins }\end{array}$ & [88] \\
\hline
\end{tabular}




\section{Types of Fiber Used in Bakery and Other Potential Types of Fiber}

Dietary fiber (DF) is the portion of plant-derived food that cannot be completely broken down by human digestive enzymes, and includes carbohydrate-based plant materials (wall polysaccharides, resistant starch and oligosaccharides) [91,92]. Depending on the solubility of the fiber, it can be classified as soluble or insoluble. Water-soluble fibers, which can be found in fruits (such as oranges, apples and grapefruit), legumes (dry beans, lentils and peas), vegetables, barley, oats and oat bran, absorb water during digestion, which increases stool bulk and may decrease blood cholesterol levels. In this case, compounds of high and medium molecular weight, such as soluble pentosans, soluble pectin, $\beta$-glucans, carragenans and gum Arabic, as well as low molecular weight fractions, such as inulin, fructooligosaccharides (FOS) galactoosaccharides (GOS), resistant maltrodextrins (RMD) and polydextrose, can be found [93]. Water-insoluble fibers, which are contained in fruits (edible peel or seeds), wholegrain products, bulgur wheat, vegetables, stone ground corn meal, cereals, bran, rolled oats and buckwheat and brown rice, do not change during digestion but stimulate peristaltic movements. They are composed of resistant starch (RS) or high and medium molecular weight fractions of cellulose, pentosans, pectin or lignin [93]. However, potential functional fiber for food may come not only from vegetables but also from animals (e.g., chitin and chitosan) and may be commercially produced (e.g., polydextrose, resistant starch, inulin and indigestible dextrins) [94] or even obtained from seaweeds [95]. Moreover, Pina-Pérez et al. [96] reviewed the most effective antimicrobial extracts from algae against foodborne pathogenic bacteria. They concluded that-as antioxidants and antimicrobials-algae have good prospects in response to the Horizon 2020 call for white label developments and innovation in sustainable food products.

It is widely known that a healthy diet based on a sufficient amount of dietary fiber may help to avoid the development of different ailments such as diabetes, hepatitis, and cardiovascular diseases, which are among the leading causes of death. Thus, dietary guidelines worldwide recommend consumption of wholegrain products as well as a daily intake of dietary fiber of $25-40 \mathrm{~g}$ for adults $[97,98]$. In fact, the European Prospective Investigation into Cancer and Nutrition (EPIC) has shown a $40 \%$ risk reduction of colorectal cancer when consuming more than $30 \mathrm{~g}$ of fiber/day $[99,100]$. However, in many western countries, diets are still often low in dietary fiber, because of the relatively low intake of edible plant tissues from vegetables, fruits and wholegrain cereal products. Hence, there is a worldwide need to develop new ingredients and foods with enhanced nutritional benefits and it is also necessary to know how properties of fiber are affected during food processing and how this can impact nutrient digestibility [92]. In this respect, the incorporation of dietary fiber into bakery products has been widely studied, since they are a staple food, which are regularly consumed by all social and age sectors. Recently, Sharma et al. [101] observed a decrease in hypocholesterolemic values in the serum of laboratory animals fed with milled muffins or cookies containing pumpkin flour.

Besides, there was a reduction in pathogens and a growth of lactic and bifidobacteria in the gastrointestinal tract of these animals. Nevertheless, the activity of all enzymes studied did not reach values comparable with those of healthy animals. However, it is important to bear in mind that the fortification of dietary fiber in food products negatively affects the product's functional properties [102,103]. Thus, Foschia et al. [104] published a review explaining the effects of different dietary fibers (inulin, fructo-oligofructose, $\beta$-glucans, arabinoxylans and resistant starch) on the quality and nutritional aspects of common foods containing cereals, such as pasta, bread, muffins/cakes and extruded snacks. In the present study, an update of that review has been carried out, and the results are shown in Table 4. Furthermore, Kadam and Prabhasankar in 2010 [95] described the status and future projections of marine functional ingredients in bakery and pasta products. Seven years later, Roohinajad et al. [105] reported the different applications of seaweeds in the development of new food products with enhanced shelf life, quality, and health-related beneficial properties. The special attention given to the role of seaweeds in these bakery products is remarkable, since they contain a significant amount of soluble and insoluble polysaccharides, and have a potential function as dietary fiber, with a higher Water Holding Capacity (WHC) than cellulosic fibers. 
Table 4. Types of fiber used in bakery along with potential replacements.

\begin{tabular}{|c|c|c|c|c|c|}
\hline Type of Fiber & Aim & $\begin{array}{l}\text { Level of Replacement } \\
\text { in Bakery/Bread/Cake }\end{array}$ & Properties in Dough & Properties in Final Product & References \\
\hline \multicolumn{6}{|c|}{ DERIVED FROM FRUITS, VEGETABLES AND GRAINS } \\
\hline Coffee silverskin & $\begin{array}{l}\text { Determine the influence } \\
\text { of coffee silverskin as a fat } \\
\text { substitution in cakes } \\
\text { treated (WTCS) or not } \\
\text { (UTCS) with water to } \\
\text { reduce bitterness }\end{array}$ & $\begin{array}{c}\text { Cakes were formulated } \\
\text { with } 0 \%, 20 \%, 25 \% \text { and } \\
30 \% \text { replacement of fat } \\
\text { with coffee silverskin }\end{array}$ & Not reported & $\begin{array}{l}\text { WTCS cakes were more similar to the } \\
\text { control cake and they were found to be } \\
\text { preferable to UTCS. Substitution of fat in } \\
\text { cakes up to } 30 \% \text { by WTCS is feasible. }\end{array}$ & [106] \\
\hline Soluble cocoa fiber & $\begin{array}{l}\text { Assess the effects of a } \\
\text { soluble cocoa fiber as a fat } \\
\text { replacer in chocolate } \\
\text { muffins and their batters }\end{array}$ & $\begin{array}{c}\text { Part of the oil ingredient } \\
(25 \%, 50 \% \text { and } 75 \%) \text { was } \\
\text { replaced by soluble cocoa } \\
\text { fiber, and control sample } \\
\text { to which cocoa powder } \\
\text { was added, } \\
\text { for comparison purposes. }\end{array}$ & $\begin{array}{c}\text { Fiber increased the } \\
\text { consistency and decreased } \\
\text { the flow index, } \\
\text { indicating a more } \\
\text { entangled structure }\end{array}$ & $\begin{array}{l}\text { Cocoa fiber gave muffins higher } \\
\text { moisture and a more tender and crumbly } \\
\text { texture, also reducing hardening during } \\
\text { storage. However, there was a loss of } \\
\text { height, bitter taste and surface stickiness. }\end{array}$ & [107] \\
\hline $\begin{array}{l}\text { Spent coffee grounds } \\
\text { (SCG) along with } \\
\text { low-calorie sweeteners } \\
\text { and oligofructose }\end{array}$ & $\begin{array}{l}\text { Evaluate the use of SCG } \\
\text { from instant coffee as a } \\
\text { food ingredient and its } \\
\text { application in bakery }\end{array}$ & $\begin{array}{l}\text { SCG added to the biscuits } \\
\text { ranged } 3.5 \%-4.4 \% \text {, } \\
\text { to achieve the nutritional } \\
\text { claims "source of fiber" } \\
\text { ( } \geq 3 \mathrm{~g} \text { fiber } / 100 \mathrm{~g} \text { biscuit) } \\
\text { and "high fiber } \\
\text { content" ( } \geq 6 \mathrm{~g} \\
\text { fiber } 100 \mathrm{~g} \text { biscuit) }\end{array}$ & Not reported & $\begin{array}{l}\text { SCG are natural source of antioxidant } \\
\text { insoluble dietary fiber, proteins, } \\
\text { essential amino acids and low } \\
\text { glycaemic sugars. SCG }(4 \% w / w) \text { can be } \\
\text { used directly as ingredient without } \\
\text { affecting the conventional food } \\
\text { preparation and the final product }\end{array}$ & [16] \\
\hline $\begin{array}{l}\text { Flour isolated from green } \\
\text { bananas }(\mathrm{GB})\end{array}$ & $\begin{array}{l}\text { Influence of wheat flour } \\
\text { replacement by GB flour, } \\
\text { with three sizes, on the } \\
\text { nutritional, physical and } \\
\text { sensory properties of } \\
\text { layer and sponge cakes. }\end{array}$ & $\begin{array}{l}\text { Wheat replacement: } 15 \% \\
\text { and } 30 \% \text { by GB flour }\end{array}$ & $\begin{array}{l}\text { BG flour reduced batter } \\
\text { density for both layer and } \\
\text { sponge cakes }\end{array}$ & $\begin{array}{c}\text { A plausible } 30 \% \text { replacement of banana } \\
\text { flour in layer cakes is demonstrated, } \\
\text { finding only a small decline in the } \\
\text { sensory perception. However, } \\
\text { sponge cakes were worsened with } \\
\text { banana flours, especially with a } \\
\text { higher size. }\end{array}$ & [108] \\
\hline
\end{tabular}


Table 4. Cont.

\begin{tabular}{|c|c|c|c|c|c|}
\hline Type of Fiber & Aim & $\begin{array}{c}\text { Level of Replacement in } \\
\text { Bakery/Bread/Cake }\end{array}$ & Properties in Dough & Properties in Final Product & References \\
\hline $\begin{array}{l}\text { Wholegrain concentrate } \\
\text { (WGC) }(6 \% \text { of total dietary } \\
\text { fiber in the end product) }\end{array}$ & $\begin{array}{l}\text { Develop healthy } \\
\text { fiber-enriched and } \\
\text { wholegrain bread } \\
\text { products with sensory } \\
\text { attributes similar to } \\
\text { white bread. }\end{array}$ & $\begin{array}{l}3000 \mathrm{~g} \text { flour or } 3000 \mathrm{~g} \\
\text { wholemeal flour or a } \\
\text { combination of } 2670 \mathrm{~g} \\
\text { refined flour and } \\
\quad 330 \mathrm{~g} \text { WGC }\end{array}$ & $\begin{array}{l}\text { Dough stickiness tended } \\
\text { to be increased when } \\
\text { refined flour was replaced } \\
\text { by wholemeal flour }\end{array}$ & $\begin{array}{l}15 \% \mathrm{WGC} \text { in bread roll increased fiber, } \\
\mathrm{Fe}, \mathrm{Mg}, \mathrm{Zn} \text { and folate. For tin breads, } \\
\text { about } 24 \% \text { WGC was required to obtain } \\
\text { this nutritional quality }\end{array}$ & [109] \\
\hline Orange fiber $(\mathrm{OF})$ & $\begin{array}{l}\text { Compare twi gluten-free } \\
\text { muffins formulated with } \\
\text { two different OF: obtained } \\
\text { by hot air coupled with } \\
\text { microwave drying (HAD } \\
+ \text { MW) of orange peels or } \\
\text { commercially available. }\end{array}$ & $\begin{array}{c}\text { Water }(43 \%) \text {, sugar }(18 \%) \text {, } \\
\text { sunflower oil }(11 \%), \\
\text { whole egg }(7 \%), \\
\text { skim milk powder }(6 \%) \text {, } \\
\text { corn starch }(5 \%), \\
\text { citrus fiber }(4.5 \%), \\
\text { rice flour }(4 \%), \\
\text { leavening agents }(1 \%), \\
\text { salt }(0.5 \%) .\end{array}$ & $\begin{array}{c}\text { Total dietary fiber, } \\
\text { water retention capacity, } \\
\text { viscosity and viscoelastic } \\
\text { properties }\left(G^{\prime} \text { and } G^{\prime \prime}\right) \\
\text { were higher for HAD + } \\
\text { MW fiber }\end{array}$ & $\begin{array}{l}\text { Panellists preferred HAD + MW muffins } \\
\text { due to their attractive color, flavor, } \\
\text { texture and chewiness. }\end{array}$ & [110] \\
\hline Chia seed mucilage $(\mathrm{CM})$ & $\begin{array}{l}\text { Extract } \mathrm{CM}, \text { dry it at } 50^{\circ} \mathrm{C} \text {, } \\
\text { or lyophilize, and } \\
\text { evaluate the effects of its } \\
\text { incorporation on the } \\
\text { technological quality of } \\
\text { breads and pound cakes }\end{array}$ & $\begin{array}{c}\text { Fat in bread and cakes } \\
\text { was replaced by CM at } \\
25 \%, 50 \%, 75 \% \text { and } 100 \% \text {. }\end{array}$ & Not reported & $\begin{array}{l}\text { Breads and chocolate cakes made with } \\
\text { CM can replace up to } 50 \% \text { of fat without } \\
\text { affecting the technological and } \\
\text { physical characteristics }\end{array}$ & [43] \\
\hline Chia seed flour & $\begin{array}{l}\text { Test the capacity of chia } \\
\text { seed flour to improve the } \\
\text { bread-making process of } \\
\text { fiber-rich dough and } \\
\text { product properties. }\end{array}$ & $\begin{array}{l}\text { Seven formulas: one with } \\
\text { wheat flour, } \\
\text { two substituting } 13 \% \text { and } \\
23 \% \text { (d.b.) of wheat flour } \\
\text { with bran, and the last } \\
\text { two were combined in } \\
\text { turn with chia } \\
\text { substituting } 5 \% \text { and } 10 \% \\
\text { (d.b.) of their wheat flour }\end{array}$ & $\begin{array}{l}\text { Chia led to an increase in } \\
\text { the gas retention of dough } \\
\text { with } 13 \% \text { of bran }\end{array}$ & $\begin{array}{l}\text { The } 13 \% \text { bran } / 5 \% \text { chia formula generated } \\
\text { breads with } 12 \% \text { fiber content had no } \\
\text { differences in specific volume and similar } \\
\text { hardness compared to the refined } \\
\text { wheat ones. The same sensory scores } \\
\text { were shown with respect to the } \\
\text { wholemeal formula without chia flour. }\end{array}$ & [111] \\
\hline Sorghum flour & $\begin{array}{l}\text { Evaluate starch, dietary } \\
\text { fiber and mineral content } \\
\text { of cookies developed from } \\
12 \text { sorghum cultivars. }\end{array}$ & $\begin{array}{l}\text { Wheat flour was totally } \\
\text { replaced by sorghum flour } \\
\text { from } 12 \text { different cultivars }\end{array}$ & Not reported & $\begin{array}{l}\text { Sorghum cookies had higher dietary fiber } \\
\text { content than control. Three selective } \\
\text { cultivars (CSH 23, CSH 13R and CSV } \\
\text { 18R) had the best acceptability and were } \\
\text { rich in nutritional qualities }\end{array}$ & {$[71]$} \\
\hline
\end{tabular}


Table 4. Cont.

\begin{tabular}{|c|c|c|c|c|c|}
\hline Type of Fiber & Aim & $\begin{array}{l}\text { Level of Replacement in } \\
\text { Bakery/Bread/Cake }\end{array}$ & Properties in Dough & Properties in Final Product & References \\
\hline Soybean meal (SBM) & $\begin{array}{l}\text { Effect of dry-heating or } \\
\text { fermentation by } \\
\text { Saccharomyces cerevisiae } \\
\text { on (SBM) composition }\end{array}$ & $\begin{array}{l}95 \% \text { of wheat flour was } \\
\text { replaced by SBM }\end{array}$ & Not reported & $\begin{array}{l}\text { SBM biscuits showed adequate } \\
\text { technological properties, } \\
\text { improved nutritional and functional } \\
\text { qualities and good sensory acceptance, } \\
\text { whereas fermented SBM biscuits } \\
\text { showed low sensory scores. }\end{array}$ & [112] \\
\hline \multicolumn{6}{|c|}{ COMMERCIALLY PRODUCED CARBOHYDRATES (OLIGOFRUCTOSE, INULIN, POLYDEXTROSE, RESISTANT STARCH) } \\
\hline $\begin{array}{l}\text { Chicory fructans: Inulin } \\
\text { Instant (inulin), Fibruline } \\
\text { DS2 (inulin) and Fibrulose } \\
\text { F97 (oligofructose) }\end{array}$ & $\begin{array}{l}\text { Effect on bread-making of } \\
\text { functional bakery goods, } \\
\text { which justifies a } \\
\text { prebiotic claim. }\end{array}$ & $\begin{array}{l}\text { Wheat flour half-white } \\
\text { with addition of } 5 \%, 10 \% \text {, } \\
15 \% \text { and } 20 \% \text { of inulin } \\
\text { (Fibruline DS2) ( } \% \\
\text { basis flour) }\end{array}$ & $\begin{array}{l}\text { Upon addition of inulin, } \\
\text { significant decrease in } \\
\text { water absorption. } \\
\text { Decreasing trend of } \\
\text { dough machinability. }\end{array}$ & $\begin{array}{l}\text { Breads had loaf volume reduced, } \\
\text { were underdeveloped, with shriveled } \\
\text { crust and irregular pores. } \\
\text { Crumbs become harder and darker, } \\
\text { but pleasant taste. Acceptability limit: } \\
\text { 5\% Fibruline DS2. }\end{array}$ & [94] \\
\hline Inulin (Frutafit $\mathrm{HD}^{\circledR}$ ) & $\begin{array}{l}\text { Improve cake quality by } \\
\text { adding an emulsifier mix } \\
\text { and a lipase into cake } \\
\text { batters in which fat was } \\
\text { replaced with inulin }\end{array}$ & $\begin{array}{c}\text { Fat-replaced }(0 \%, 50 \% \text { and } \\
70 \%) \text { with inulin }(0,7.5 \\
\text { and } 10 / 100 \mathrm{~g} \text { of } \\
\text { flour, respectively). } \\
\text { Dispersion } \\
\text { inulin-to-water, } 1: 2 \text { was } \\
\text { added as a fat mimetic }\end{array}$ & $\begin{array}{l}\text { Lipase reduces the degree } \\
\text { of system structuring, } \\
\text { whereas emulsifier } \\
\text { increases } \\
\text { batter consistency. }\end{array}$ & $\begin{array}{l}\text { Good-quality cakes with } 50 \% \text { and } 70 \% \\
\text { fat replacement can be obtained using } \\
\text { lipase or emulsifier at low levels }\end{array}$ & [113] \\
\hline $\begin{array}{c}\text { Hydroxypropyl } \\
\text { methylcellulose (HPMC) } \\
\text { and inulin (Frutafit HD }{ }^{\circledR} \text { ) }\end{array}$ & $\begin{array}{l}\text { Study the effect of partial } \\
\text { fat replacement with } \\
\text { inulin and HPMC } \\
\text { in biscuits. Texture was } \\
\text { studied by fracture and } \\
\text { sound } \\
\text { emission measurement. }\end{array}$ & $\begin{array}{l}15 \text { and } 30 / 100 \mathrm{~g} \text { of the fat } \\
\text { has been replaced by two } \\
\text { different } \\
\text { carbohydrate-based fat } \\
\text { replacers (inulin } \\
\text { and HPMC) }\end{array}$ & Not reported & $\begin{array}{c}\text { Biscuits with Inulin and (HPMC) were } \\
\text { harder and with higher sound emissions } \\
\text { for control. } 15 / 100 \mathrm{~g} \text { with inulin or } \\
\text { HPMC provided acceptable biscuits, } \\
\text { but a higher replacement decreased } \\
\text { the acceptability. }\end{array}$ & [114] \\
\hline $\begin{array}{l}\text { Partially hydrolyzed guar } \\
\text { gum (PHGG) }\end{array}$ & $\begin{array}{l}\text { Effect of PHGG and water } \\
\text { on physical and sensory } \\
\text { properties of bread }\end{array}$ & $\begin{array}{c}\text { Refined wheat flour was } \\
\text { mixed with PHGG at } 1 \% \text {, } \\
1.59 \%, 3.0 \%, 4.41 \% \text { and } \\
5.0 \%\end{array}$ & $\begin{array}{l}\text { PHGG increased the } \\
\text { dough strength }\end{array}$ & $\begin{array}{l}\text { PHGG improved textural properties of } \\
\text { bread }\end{array}$ & [103] \\
\hline
\end{tabular}


Table 4. Cont.

\begin{tabular}{|c|c|c|c|c|c|}
\hline Type of Fiber & Aim & $\begin{array}{l}\text { Level of Replacement in } \\
\text { Bakery/Bread/Cake }\end{array}$ & Properties in Dough & Properties in Final Product & References \\
\hline \multicolumn{6}{|c|}{ DERIVED FROM ALGAE } \\
\hline $\begin{array}{l}\text { Microalgae Chlorella } \\
\text { vulgaris }(\mathrm{CV})\end{array}$ & $\begin{array}{l}\text { Addition of CV in a wheat } \\
\text { flour to evaluate dough } \\
\text { rheology and } \\
\text { bread texture }\end{array}$ & $\begin{array}{l}\text { Microalgae contents from } \\
1.0 \text { to } 5.0 \mathrm{~g} \text { per } 100 \mathrm{~g} \text { of } \\
\text { wheat flour were tested }\end{array}$ & $\begin{array}{l}\text { Up to } 3.0 \mathrm{~g} \text { of } \mathrm{CV} \text { : positive } \\
\text { impact on dough rheology, } \\
\text { viscoelastic properties and } \\
\text { gluten network } \\
\text { strengthening }\end{array}$ & $\begin{array}{c}\text { up to } 3.0 \mathrm{~g} \mathrm{CV} / 100 \mathrm{~g} W F \text { addition } \\
\text { resulted in breads with an } \\
\text { interesting appearance, but with a higher } \\
\mathrm{CV} \text {, global aspect was worsened. }\end{array}$ & [115] \\
\hline $\begin{array}{l}\text { Fucus vesiculosus seaweed } \\
\text { powder (FV) }\end{array}$ & $\begin{array}{l}\text { Effect FV addition up to } \\
8 \% \text { on wheat flour dough } \\
\text { and bread properties }\end{array}$ & $\begin{array}{c}2 \%, 4 \%, 6 \% \text {, and } 8 \% \text { of } \\
\text { seaweed powder (flour } \\
\text { basis, f.b.) }\end{array}$ & $\begin{array}{l}\text { FV raised elongation } \\
\text { dough viscosity and } \\
\text { consistency index }\end{array}$ & $\begin{array}{l}\text { A maximum of } 4 \% \mathrm{FV} \text { could be added, } \\
\text { without impairing the density and } \\
\text { crumb texture of enriched bread }\end{array}$ & [116] \\
\hline Brown algae (BA) & $\begin{array}{l}\text { Influence of BA on } \\
\text { physical, antioxidant, } \\
\text { and sensorial properties } \\
\text { in gluten-free bread }\end{array}$ & $\begin{array}{c}2 \%, 4 \%, 6 \%, 8 \% \text {, and } 10 \% \\
\text { of the total flour content }\end{array}$ & Not reported & $\begin{array}{c}\text { A larger volume was obtained using } 4 \% \\
\text { of algae. Lightness and yellowness of } \\
\text { breadcrumb decreased with the addition } \\
\text { of BA. }\end{array}$ & [117] \\
\hline \multicolumn{6}{|c|}{ DERIVED FROM ANIMALS } \\
\hline Chitosan & $\begin{array}{l}\text { Effect of chitosan on the } \\
\text { sensory properties and } \\
\text { the shelf-life of cupcake }\end{array}$ & $\begin{array}{l}\text { Cupcakes with shrimp } \\
\text { shells chitosan } \\
\text { concentrations } 0 \%, 0.5 \% \text {, } \\
1 \%, 1.5 \%, 2 \% \text { and } 2.5 \%\end{array}$ & Not reported & $\begin{array}{l}1.5 \% \text { of improved sensory properties and } \\
\text { prolonged the shelf life of cupcakes. }\end{array}$ & [118] \\
\hline $\begin{array}{l}\text { Chitosan and chitosan } \\
\text { oligosaccharides }\end{array}$ & $\begin{array}{l}\text { Investigate the effects of } \\
\text { chitosan oligosaccharides } \\
\text { and chitosan on the rate of } \\
\text { staling and the properties } \\
\text { of bread crumb and crust. }\end{array}$ & $\begin{array}{l}2.18 \% \text { of batter } \\
\text { formulation was } \\
\text { composed by chitosan or } \\
\text { different types of } \\
\text { chitosan oligosaccharides }\end{array}$ & Not reported & $\begin{array}{c}\text { Chitosan oligosaccharides and low } \\
\text { molecular weight chitosan increased } \\
\text { bread crumb staling rate to a much lesser } \\
\text { extent than middle molecular } \\
\text { weight chitosan }\end{array}$ & [119] \\
\hline Chitosan & $\begin{array}{l}\text { Effect of chitosan on } \\
\text { acrylamide and HMF in } \\
\text { model systems and in } \\
\text { biscuit and crust models. }\end{array}$ & $\begin{array}{l}\text { Appropriate amounts of } \\
\text { Asn and Glc dissolved in } \\
1 \% \text { chitosan solution. } \\
\text { In biscuits, water was } \\
\text { replaced with } 0.5 \% \\
\text { chitosan in } 1 \% \\
\text { formic acid. }\end{array}$ & No reported & $\begin{array}{l}\text { Chitosan did not significantly affect the } \\
\text { formation of acrylamide in biscuit and } \\
\text { crust models during heating. }\end{array}$ & [120] \\
\hline
\end{tabular}


Moreover, for the celiac population, the needs of dietary fiber are especially important, since most of the cereal-based gluten-free products are usually made with starches and/or refined flours, and therefore low in fiber, so it is necessary to improve their nutritional quality [121]. In this regard, Talens et al. [110] compared the physico-chemical properties of a new orange fiber ingredient obtained by hot air coupled with microwave (HAD + MW) with a commercial citrus fiber and they also studied the differences between gluten-free muffins formulated with both orange fibers. According to the sensorial analysis, panelists preferred muffins with HAD + MW fiber to those with commercial fiber. Thereby, they concluded that the application of HAD + MW drying may be a new alternative for citrus by-product valorization and transformation into a fiber ingredient suitable for gluten-free baking. In this line, Różyło et al. [117] studied the influence of brown algae addition on the physical, antioxidant, and sensorial properties of gluten-free bread (GFB). They concluded that an acceptable GFB could be obtained by adding $2 \%$ or $4 \%$ of the algae.

\section{Conclusions}

Due to the evident relationship between diet and health, there is a growing interest in improving the nutritional profile of most food products, especially those with high sugar and fat contents. Bakery products are consumed by all sectors of the society regardless of age and income level.

A major conclusion to be drawn in this field is that current research efforts are bearing fruit. In bakery products, traditional ingredients providing carbohydrates, proteins, and fats may be successfully replaced by other, healthier substances, without nutritional quality loss. The different approaches described in this review seem to corroborate this claim.

As recommended by international organizations, such as the WHO (World Health Organization), this paper demonstrates the feasibility of replacing critical ingredients in bakery products with other healthier substances-the resulting products still being acceptable for the consumer. Nevertheless, although all published articles are focused on the nutritional improvement caused by the replacement of some ingredients, there remains the problem of the combined effect of the simultaneous substitution of several of them.

Author Contributions: All authors contributed to the manuscript. Conceptualization, M.D.O., M.P. and M.L.C.; Validation, investigation, resources, data curation, writing—all authors; Review and editing, M.D.O., M.P., M.L.C., and S.R.-A. All the authors read and approved the final manuscript.

Acknowledgments: This work was supported by the Generalitat Valenciana (AICO/2017/043).

Conflicts of Interest: The authors declare no conflict of interest.

\section{References}

1. Eswaran, S.; Muir, J.; Chey, W.D. Fiber and functional gastrointestinal disorders. Am. J. Gastroenterol. 2013, 108, 718-727. [CrossRef] [PubMed]

2. Rosell, C.M.; Garzon, R. Chemical composition of bakery products. In Handbook of Food Chemistry; Cheung, P.C.K., Ed.; Springer: Berlin, Germany, 2015.

3. Martins, Z.E.; Pinho, O.; Ferreira, I.M.P.L.V.O. Review. Food industry by-products used as functional ingredients of bakery products. Trends Food Sci. Technol. 2017, 67, 106-128. [CrossRef]

4. World Health Organization WHO. Guideline: Sugars Intake for Adults and Children; World Health Organization Document Production Services: Geneva, Switzerland, 2015; Available online: http://apps.who.int/iris/ bitstream/10665/149782/1/9789241549028_eng.pdf?ua=1 (accessed on 16 October 2019).

5. World Health Organization WHO. Obesity and Overweight. Descriptive Note; World Health Organization Document Production Services: Geneva, Switzerland, 2016; Available online: http://www.who.int/ mediacentre/factsheets/fs311/es/ (accessed on 16 October 2019).

6. O'Keefe, S.F.; Sarnoski, P.J. Nomenclature and classification of lipids. In Food Lipids: Chemistry, Nutrition and Biotechnology; Akoh, C.C., Ed.; CRC Press: Boca Raton, FL, USA, 2017.

7. Rohm, H.; Schaper, C.; Zahn, S. Interesterified fats in chocolate and bakery products: A concise review. LWT-Food Sci. Technol. 2018, 87, 379-384. [CrossRef] 
8. Lina, B.A.R.; Jonker, D.; Kozianowski, G. Isomaltulose (Palatinose $\left.{ }^{\circledR}\right)$ : A review of biological and toxicological studies. Food Chem. Toxicol. 2002, 40, 1375-1381. [CrossRef]

9. Lu, Y.; Levin, G.V.; Donner, T.W. Tagatose, a new antidiabetic and obesity control drug. Diabetes Obes. Metab. 2008, 10, 109-134. [CrossRef]

10. Rubio-Arraez, S.; Benavent, C.; Ortolá, M.D.; Castelló, M.L. Influence of low glycemic index sweeteners on antioxidant, sensory, mechanical, and physicochemical properties of a watermelon jelly. J. Food Qual. 2018, 2018, 8412017. [CrossRef]

11. Rodríguez, A.; Magan, N.; Medina, A. Evaluation of the risk of fungal spoilage when substituting sucrose with commercial purified Stevia glycosides in sweetened bakery products. Int. J. Food Microbiol. 2016, 231, 42-47. [CrossRef]

12. Abdalbasit, A.; Gasmalla, M.; Yang, R.; Hua, X. Stevia rebaudiana Bertoni: An alternative sugar replacer and its application in food industry. Food Eng. Rev. 2014, 6, 150-162.

13. Trattner, S.; Becker, W.; Wretling, S.; Öhrvik, V.; Mattisson, I. Fatty acid composition of Swedish bakery products, with emphasis on trans-fatty acids. Food Chem. 2015, 175, 423-430. [CrossRef]

14. Esfahani, A.; Wong, J.M.W.; Mirrahimi, A.; Villa, C.R.; Kendall, C.W.C. The application of the glycemic index and glycemic load in weight loss: A review of the clinical evidence. IUBMB Life 2011, 63, 7-13. [CrossRef]

15. Dyshlyuk, L.; Babich, O.; Prosekov, A.; Ivanova, S.; Pavsky, V.; Yang, Y. In vivo study of medical and biological properties of functional bakery products with the addition of pumpkin flour. Bioact. Carbohydr. Diet. Fibre 2017, 12, 20-24. [CrossRef]

16. Martinez-Saez, N.; Tamargo García, A.; Domínguez Pérez, I.; Rebollo-Hernanz, M.; Mesías, M.; Morales, F.J.; Martín-Cabrejas, M.A.; del Castillo, M.D. Use of spent coffee grounds as food ingredient in bakery products. Food Chem. 2017, 216, 114-122. [CrossRef] [PubMed]

17. Duodu, K.G. Effects of processing on antioxidant phenolics of cereal and legume grains. In Advances in Cereal Science: Implications to Food Processing and Health Promotion; Awika, J.M., Piironen, V., Bean, S., Eds.; American Chemical Society: Washington, DC, USA, 2011.

18. Abdel-Aal, E.M.; Rabalski, I. Effect of baking on free and bound phenolic acids in wholegrain bakery products. J. Cereal Sci. 2013, 57, 312-318. [CrossRef]

19. Purlis, E. Browning development in bakery products-A review. J. Food Eng. 2010, 99, 239-249. [CrossRef]

20. European Commission EU. The Competitive Position of the European Food and Drink Industry: Final Report; Publications Office of the European Union: Luxembourg, 2016; Available online: https://www.fooddrinkeurope.eu/uploads/publications_documents/Competitive_food_industry_ growth_jobs_report.pdf (accessed on 16 October 2019).

21. European Commission EU. Commission Regulation (EC) No 1169/2011 of the European Parliament and of the Council of 25 October 2011 on the Provision of Food Information to Consumers; Official Journal of the European Union: Luxembourg, 2011; Available online: https://eur-lex.europa.eu/legal-content/EN/TXT/HTML/?uri=CELEX: 32011R1169\&from =EN (accessed on 16 October 2019).

22. Liang, S.; Were, L.M. Chlorogenic acid oxidation-induced greening of sunflower butter cookies as a function of different sweeteners and storage conditions. Food Chem. 2018, 241, 135-142. [CrossRef]

23. Karp, S.; Wyrwisz, J.; Kurek, M.; Wierzbicka, A. Physical properties of muffins sweetened with steviol glycosides as the sucrose replacement. Food Sci. Biotechnol. 2016, 25, 1591-1596. [CrossRef]

24. Zahn, S.; Forker, A.; Krügel, L.; Rohm, H. Combined use of rebaudioside A and fibres for partial sucrose replacement in muffins. LWT-Food Sci. Technol. 2013, 50, 695-701. [CrossRef]

25. Patel, S.; Goyal, A. Functional oligosaccharides: Production, properties and applications. World J. Microbiol. Biotechnol. 2011, 27, 1119-1128. [CrossRef]

26. Tavera-Quiroz, M.J.; Urriza, M.; Pinotti, A.; Bertola, N. Baked snack from Green apples formulated with the addition of isomalt. LWT-Food Sci. Technol. 2015, 62, 1004-1010. [CrossRef]

27. Struck, S.; Jaros, D.; Brennan, C.S.; Rohm, H. Sugar replacement in sweetened bakery goods. Int. J. Food Sci. Technol. 2014, 49, 1963-1976. [CrossRef]

28. Ghosh, S.; Sudha, M.L. A review on polyols: New frontiers for health-based bakery products. Int. J. Food Sci. Nutr. 2012, 63, 372-379. [CrossRef] [PubMed]

29. Regnat, K.; Mach, R.L.; Mach-Aigner, A.R. Erythriol as sweetener-where from and where to? Appl. Microbiol. Biotechnol. 2018, 102, 587-595. [CrossRef] [PubMed] 
30. Singla, V.; Chakkaravarthi, S. Applications of prebiotics in food industry: A review. Food Sci. Technol. Int. 2017, 23, 649-667. [CrossRef] [PubMed]

31. Rios, R.V.; Pessanha, M.D.F.; Almeida, P.F.; Viana, C.L.; Lannes, S.C.S. Application of fats in some food products. Food Sci. Technol. 2014, 34, 3-15. [CrossRef]

32. Wilderjans, E.; Luyts, A.; Brijs, K.; Delcour, J.A. Ingredient functionality in batter type cake making. Trends Food Sci. Technol. 2013, 30, 6-15. [CrossRef]

33. Ballesteros-Vásquez, M.N.; Valenzuela-Calvillo, L.S.; Artalejo-Ochoa, E.; Robles-Sardin, A.E. Ácidos grasos trans: Un análisis del efecto de su consumo en la salud humana, regulación del contenido en alimentos y alternativas para disminuirlos. Nutrición Hospitalaria 2012, 27, 54-64.

34. Zettel, V.; Hitzmann, B. Chia (Salvia hispanica L.) as fat replacer in sweet pan breads. Int. J. Food Sci. Technol. 2016, 51, 1425-1432. [CrossRef]

35. Doménech-Asensi, G.; Merola, N.; López-Fernández, A.; Ros-Berruezo, G.; Frontela-Saseta, C. Influence of the reformulation of ingredients in bakery products on healthy characteristics and acceptability of consumers. Int. J. Food Sci. Nutr. 2016, 67, 74-82. [CrossRef]

36. Umesha, S.S.; Manohar, R.S.; Indiramma, A.R.; Akshitha, S.; Naidu, K.A. Enrichment of biscuits with microencapsulated omega-3 fatty acid (Alpha-linolenic acid) rich Garden cress (Lepidium sativum) seed oil: Physical, sensory and storage quality characteristics of biscuits. LWT_Food Sci. Technol. 2015, 62, 654-661. [CrossRef]

37. Rajiv, J.; Indrani, D.; Prabhasankar, P.; Rao, G.V. Rheology, fatty acid profile and storage characteristics of cookies as influenced by flax seed (Linum usitatissimum). J. Food Sci. Technol. 2012, 49, 587-593. [CrossRef]

38. Mesías, M.; Holgado, F.; Márquez-Ruiz, G.; Morales, F.J. Risk/benefit considerations of a new formulation of wheat-based biscuit supplemented with different amounts of chia flour. LWT_Food Sci. Technol. 2016, 73, 528-535. [CrossRef]

39. Pizarro, P.L.; Almeida, E.L.; Sammán, N.C.; Chang, Y.K. Evaluation of whole chia (Salvia hispanica L.) flour and hydrogenated vegetable fat in pound cake. LWT_Food Sci. Technol. 2013, 54, 73-79. [CrossRef]

40. Coelho, M.S.; de las Mercedes Salas-Mellado, M. Effects of substituting chia (Salvia hispanica L.) flour or seeds for wheat flour on the quality of the bread. LWT-Food Sci. Technol. 2015, 60, 729-736. [CrossRef]

41. Vázquez-Ovando, A.; Rosado-Rubio, G.; Chel-Guerrero, L.; Betancur-Ancona, D. Physicochemical properties of a fibrous fraction from chia (Salvia hispanica L.). Food Sci. Technol. 2009, 42, 168-173.

42. Borneo, R.; Aguirre, A.; León, A.E. Chia (Salvia hispanica L) gel can be used as egg or oil replacer in cake formulations. J. Am. Diet. Assoc. 2010, 110, 946-949. [CrossRef]

43. Fernandes, S.S.; de las Mercedes Salas-Mellado, M. Addition of chia seed mucilage for reduction of fat content in bread and cakes. Food Chem. 2017, 227, 237-244. [CrossRef]

44. de Souza, N.C.O.; de Oliveira, L.D.L.; de Alencar, E.R.; Moreira, G.P.; dos Santos Leandro, E.; Ginani, V.C.; Zandonadi, R.P. Textural, physical and sensory impacts of the use of green banana puree to replace fat in reduced sugar pound cakes. LWT-Food Sci. Technol. 2018, 89, 617-623. [CrossRef]

45. Tarancón, P.; Fiszman, S.M.; Salvador, A.; Tárrega, A. Formulating biscuits with healthier fats. Consumer profiling of textural and flavour sensations during consumption. Food Res. Int. 2013, 53, 134-140.

46. Chugh, B.; Singh, G.; Kumbhar, B.K. Development of low-fat soft dough biscuits using carbohydrate-based fat replacers. Int. J. Food Sci. 2013, 2013, 576153. [CrossRef]

47. Martínez-Cervera, S.; Salvador, A.; Sanz, T. Cellulose ether emulsions as fat replacers in muffins: Rheological, thermal and textural properties. LWT-Food Sci. Technol. 2015, 63, 1083-1090. [CrossRef]

48. Colla, K.; Gamlath, S. Inulin and maltodextrin can replace fat in baked savoury legume snacks. Int. J. Food Sci. Technol. 2015, 50, 2297-2305. [CrossRef]

49. Forker, A.; Zahn, S.; Rohm, H. A combination of fat replacers enables the production of fat-reduced shortdough biscuits with high-sensory quality. Food Bioprocess Technol. 2012, 5, 2497-2505. [CrossRef]

50. Aggarwal, D.; Sabikhi, L.; Kumar, M.S. Formulation of reduced-calorie biscuits using artificial sweeteners and fat replacer with dairy-multigrain approach. NFS J. 2016, 2, 1-7. [CrossRef]

51. Singh, A.; Kumar, P. Gluten free approach in fat and sugar amended biscuits: A healthy concern for obese and diabetic individuals. J. Food Process. Preserv. 2018, 42, 13546. [CrossRef]

52. Laguna, L.; Varela, P.; Salvador, A.; Sanz, T.; Fiszman, S.M. Balancing texture and other sensory features in reduced fat short-dough biscuits. J. Texture Stud. 2012, 43, 235-245. [CrossRef] 
53. Błońska, A.; Marzec, A.; Błaszczyk, A. Instrumental Evaluation of Acoustic and Mechanical Texture Properties of Short-Dough Biscuits with Different Content of Fat and Inulin. J. Texture Stud. 2014, 45, 226-234. [CrossRef]

54. Giarnetti, M.; Paradiso, V.M.; Caponio, F.; Summo, C.; Pasqualone, A. Fat replacement in shortbread cookies using an emulsion filled gel based on inulin and extra virgin olive oil. LWT_Food Sci. Technol. 2015, 63, 339-345. [CrossRef]

55. Kaushik, P.; Dowling, K.; Barrow, C.J.; Adhikari, B. Microencapsulation of omega-3 fatty acids: A review of microencapsulation and characterization methods. J. Funct. Foods 2015, 19, 868-881. [CrossRef]

56. O'Dwyer, S.P.; O’Beirne, D.; Eidhin, D.N.; O'Kennedy, B.T. Effects of emulsification and microencapsulation on the oxidative stability of camelina and sunflower oils. J. Microencapsul. 2013, 30, 451-459. [CrossRef]

57. Muñoz, L.A.; Cobos, A.; Diaz, O.; Aguilera, J.M. Chia seeds: Microstructure, mucilage extraction and hydration. J. Food Eng. 2012, 108, 216-224. [CrossRef]

58. Felisberto, M.H.F.; Wahanik, A.L.; Gomes-Ruffi, C.R.; Clerici, M.T.P.S.; Chang, Y.K.; Steel, C.J. Use of chia (Salvia hispanica L.) mucilage gel to reduce fat in pound cakes. LWT_Food Sci. Technol. 2015, 63, 1049-1055. [CrossRef]

59. Quiles, A.; Llorca, E.; Schmidt, C.; Reißner, A.M.; Struck, S.; Rohm, H.; Hernando, I. Use of berry pomace to replace flour, fat or sugar in cakes. Int. J. Food Sci. Technol. 2018, 53, 1579-1587. [CrossRef]

60. Othman, N.A.; Abdul Manaf, M.; Harith, S.; Wan Ishak, W.R. Influence of Avocado Purée as a Fat Replacer on Nutritional, Fatty Acid, and Organoleptic Properties of Low-Fat Muffins. J. Am. Coll. Nutr. 2018, 37, 583-588. [CrossRef] [PubMed]

61. Romanchik-Cerpovicz, J.E.; Tilmon, R.W.; Baldree, K.A. Moisture retention and consumer acceptability of chocolate bar cookies prepared with okra gum as a fat ingredient substitute. J. Am. Diet. Assoc. 2002, 102, 1301-1303. [CrossRef]

62. Geera, B.; Reiling, J.A.; Hutchison, M.A.; Rybak, D.; Santha, B.; Ratnayake, W.S. A comprehensive evaluation of egg and egg replacers on the product quality of muffins. J. Food Qual. 2011, 34, 333-342. [CrossRef]

63. Sciarini, L.S.; Ribotta, P.D.; León, A.E.; Pérez, G.T. Influence of gluten-free flours and their mixtures on batter properties and bread quality. Food Bioprocess Technol. 2010, 3, 577-585. [CrossRef]

64. Chung, H.J.; Cho, A.; Lim, S.T. Utilization of germinated and heat-moisture treated brown rices in sugar-snap cookies. LWT-Food Sci. Technol. 2014, 57, 260-266. [CrossRef]

65. Bourekoua, H.; Benatallah, L.; Zidoune, M.N.; Rosell, C.M. Developing gluten free bakery improvers by hydrothermal treatment of rice and corn flours. LWT_Food Sci. Technol. 2016, 73, 342-350. [CrossRef]

66. Skendi, A.; Mouselemidou, P.; Papageorgiou, M.; Papastergiadis, E. Effect of acorn meal-water combinations on technological properties and fine structure of gluten-free bread. Food Chem. 2018, 253, 119-126. [CrossRef]

67. Pasqualone, A.; Makhlouf, F.Z.; Barkat, M.; Difonzo, G.; Summo, C.; Squeo, G.; Caponio, F. Effect of acorn flour on the physico-chemical and sensory properties of biscuits. Heliyon 2019, 5, e02242. [CrossRef]

68. de la Luz Guerrero-Elizarraráz, M.; Mares-Mares, E.; Sosa-Morales, M.E. Physicochemical, sensory and nutritional evaluation of gluten-free bread based on rice and soybean flour Introduction. Am. Soc. Agricult. Biologic Eng. 2017. [CrossRef]

69. Velázquez, N.; Sánchez, H.; Osella, C.; Santiago, L.G. Using white sorghum flour for gluten-free breadmaking. Int. J. Food Sci. Nutr. 2012, 63, 491-497. [CrossRef] [PubMed]

70. Marston, K.; Khouryieh, H.; Aramouni, F. Effect of heat treatment of sorghum flour on the functional properties of gluten-free bread and cake. LWT_Food Sci. Technol. 2016, 65, 637-644. [CrossRef]

71. Rao, B.D.; Anis, M.; Kalpana, K.; Sunooj, K.V.; Patil, J.V.; Ganesh, T. Influence of milling methods and particle size on hydration properties of sorghum flour and quality of sorghum biscuits. LWT-Food Sci. Technol. 2016, 67, 8-13.

72. Burešová, I.; Tokár, M.; Mareček, J.; Hřivna, L.; Faměra, O.; Šottníková, V. The comparison of the effect of added amaranth, buckwheat, chickpea, corn, millet and quinoa flour on rice dough rheological characteristics, textural and sensory quality of bread. J. Cereal Sci. 2017, 75, 158-164. [CrossRef]

73. Rai, S.; Kaur, A.; Singh, B. Quality characteristics of gluten free cookies prepared from different flour combinations. J. Food Sci. Technol. 2014, 51, 785-789. [CrossRef]

74. Chappalwar, V.M.; Peter, D.; Bobde, H.; John, S.M. Quality characteristics of cookies prepared from oats and finger millet-based composite flour. Int. J. Eng. Sci. Technol. 2013, 3, 677-683.

75. Chauhan, A.; Saxena, D.C.; Singh, S. Physical, textural, and sensory characteristics of wheat and amaranth flour blend cookies. Cogent Food Agric. 2016, 2, 1125773. [CrossRef] 
76. Chauhan, A.; Saxena, D.C.; Singh, S. Total dietary fibre and antioxidant activity of gluten free cookies made from raw and germinated amaranth (Amaranthus spp.) flour. LWT_Food Sci. Technol. 2015, 63, 939-945. [CrossRef]

77. Inglett, G.E.; Chen, D.; Liu, S.X. Physical properties of gluten-free sugar cookies made from amaranth-oat composites. LWT_Food Sci. Technol. 2015, 63, 214-220. [CrossRef]

78. Yamsaengsung, R.; Berghofer, E.; Schoenlechner, R. Physical properties and sensory acceptability of cookies made from chickpea addition to white wheat or whole wheat flour compared to gluten-free amaranth or buckwheat flour. Int. J. Food Sci. Technol. 2012, 47, 2221-2227. [CrossRef]

79. Brito, I.L.; de Souza, E.L.; Felex, S.S.S.; Madruga, M.S.; Yamashita, F.; Magnani, M. Nutritional and sensory characteristics of gluten-free quinoa (Chenopodium quinoa Willd)-based cookies development using an experimental mixture design. J. Food Sci. Technol. 2015, 52, 5866-5873. [CrossRef] [PubMed]

80. Watanabe, K.; Kawanishi-Asaoka, M.; Myojin, C.; Awata, S.; Ofusa, K.; Kodama, K. Amino acid composition, oxidative stability, and consumer acceptance of cookies made with quinoa flour. Food Sci. Technol. Res. 2014, 20, 687-691. [CrossRef]

81. Bick, M.A.; de Oliveira Fogaça, A.; Storck, C.R. Cookies with different concentrations of quinoa flour in partial replacement of wheat flour. Braz. J. Food Technol. 2014, 17, 121-129. [CrossRef]

82. Jan, U.; Gani, A.; Ahmad, M.; Shah, U.; Baba, W.N.; Masoodi, F.A. Characterization of cookies made from wheat flour blended with buckwheat flour and effect on antioxidant properties. J. Food Sci. Technol. 2015, 52, 6334-6344. [CrossRef] [PubMed]

83. Sakač, M.; Pestorić, M.; Mišan, A.; Nedeljković, N.; Jambrec, D.; Jovanov, P.; Banjac, V.; Torbica, A.; Hadnađev, M.; Mandićet, A. Antioxidant capacity, mineral content and sensory properties of gluten-free rice and buckwheat cookies. Food Technol. Biotechnol. 2015, 53, 38-47. [CrossRef] [PubMed]

84. Hadnađev, T.R.D.; Torbica, A.M.; Hadnađev, M.S. Influence of buckwheat flour and carboxymethyl cellulose on rheological behaviour and baking performance of gluten-free cookie dough. Food Bioprocess Technol. 2013, 6, 1770-1781. [CrossRef]

85. Miñarro, B.; Albanell, E.; Aguilar, N.; Guamis, B.; Capellas, M. Effect of legume flours on baking characteristics of gluten-free bread. J. Cereal Sci. 2012, 56, 476-481. [CrossRef]

86. Cheng, Y.F.; Bhat, R. Functional, physicochemical and sensory properties of novel cookies produced by utilizing underutilized jering (Pithecellobium jiringa Jack.) legume flour. Food Biosci. 2016, 14, 54-61. [CrossRef]

87. Mancebo, C.M.; Rodriguez, P.; Gómez, M. Assessing rice flour-starch-protein mixtures to produce gluten free sugar-snap cookies. LWT-Food Sci. Technol. 2016, 67, 127-132. [CrossRef]

88. Pasqualone, A.; De Angelis, D.; Squeo, G.; Difonzo, G.; Caponio, F.; Summo, C. The Effect of the Addition of Apulian black Chickpea Flour on the Nutritional and Qualitative Properties of Durum Wheat-Based Bakery Products. Foods 2019, 8, 504. [CrossRef] [PubMed]

89. de la Hera, E.; Ruiz-París, E.; Oliete, B.; Gómez, M. Studies of the quality of cakes made with wheat-lentil composite flours. LWT-Food Sci. Technol. 2012, 49, 48-54. [CrossRef]

90. Lasa, A.; del Pilar Fernández-Gil, M.; Bustamante, M.Á.; Miranda, J. Nutritional and Sensorial Aspects of Gluten-Free Products. In Nutritional and Analytical Approaches of Gluten-Free Diet in Celiac Disease; Springer: Cham, Switzerland, 2017; pp. 59-78.

91. Jones, J.M. CODEX-aligned dietary fiber definitions help to bridge the 'fiber gap'. Nutr. J. 2014, 13, 34. [CrossRef] [PubMed]

92. Grundy, M.M.L.; Edwards, C.H.; Mackie, A.R.; Gidley, M.J.; Butterworth, P.J.; Ellis, P.R. Re-evaluation of the mechanisms of dietary fibre and implications for macronutrient bioaccessibility, digestion and postprandial metabolism. Br. J. Nutr. 2016, 116, 816-833. [CrossRef]

93. Hollmann, J.; Themeier, H.; Neese, U.; Lindhauer, M.G. Dietary fibre fractions in cereal foods measured by a new integrated AOAC method. Food Chem. 2013, 140, 586-589. [CrossRef]

94. Sirbu, A.; Arghire, C. Functional bread: Effect of inulin-type products addition on dough rheology and bread quality. J. Cereal Sci. 2017, 75, 220-227. [CrossRef]

95. Kadam, S.U.; Prabhasankar, P. Marine foods as functional ingredients in bakery and pasta products. Food Res. Int. 2010, 43, 1975-1980. [CrossRef] 
96. Pina-Pérez, M.C.; Rivas, A.; Martínez, A.; Rodrigo, D. Antimicrobial potential of macro and microalgae against pathogenic and spoilage microorganisms in food. Review article. Food Chem. 2017, 235, 34-44. [CrossRef]

97. European Food Safety Agency, EFSA. Scientific opinion on dietary reference values for carbohydrates and dietary fibre. EFSA J. 2010, 8, 1462.

98. Van der Kamp, J.W.; Lupton, J. Definitions, regulations, and health claims associated with dietary fibre and wholegrain foods. In Fibre-Rich and Wholegrain Foods; Delcour, J.A., Poutanen, K., Eds.; Woodhead Publishing: Cambridge, UK, 2013.

99. Bingham, S.; Riboli, E. Diet and cancer-The European prospective investigation into cancer and nutrition. Nat. Rev. Cancer 2004, 4, 206-215. [CrossRef]

100. University of California, San Francisco UCSF. Health; University of California, San Francisco UCSF: San Francisco, CA, USA, 2018; Available online: https://www.ucsfhealth.org/education/increasing_fiber_intake/ (accessed on 16 October 2019).

101. Sharma, G.; Lakhawat, S. Development, Quality Evaluation and Acceptability of Pumpkin Seed Flour Incorporated in Gravy. J. Nutr. Food Sci. 2017, 7, 4.

102. Shukla, K.; Srivastava, S. Evaluation of finger millet incorporated noodles for nutritive value and glycemic index. J. Food Sci. Technol. 2014, 51, 527-534. [CrossRef] [PubMed]

103. Mudgil, D.; Barak, S.; Khatkar, B.S. Optimization of bread firmness, specific loaf volume and sensory acceptability of bread with soluble fiber and different water levels. J. Cereal Sci. 2016, 70, 186-191. [CrossRef]

104. Foschia, M.; Peressini, D.; Sensidoni, A.; Brennan, C.S. The effects of dietary fibre addition on the quality of common cereal products. J. Cereal Sci. 2013, 58, 216-227. [CrossRef]

105. Roohinejad, S.; Koubaa, M.; Barba, F.J.; Saljoughian, S.; Amid, M.; Greiner, R. Application of seaweeds to develop new food products with enhanced shelf-life, quality and health-related beneficial properties. Food Res. Int. 2017, 99, 1066-1083. [CrossRef] [PubMed]

106. Ateş, G.; Elmac1, Y. Coffee silverskin as fat replacer in cake formulations and its effect on physical, chemical and sensory attributes of cakes. LWT-Food Sci. Technol. 2018, 90, 519-525. [CrossRef]

107. Martínez-Cervera, S.; Salvador, A.; Muguerza, B.; Moulay, L.; Fiszman, S.M. Cocoa fibre and its application as a fat replacer in chocolate muffins. LWT_Food Sci. Technol. 2011, 44, 729-736. [CrossRef]

108. Segundo, C.; Román, L.; Gómez, M.; Martínez, M.M. Mechanically fractionated flour isolated from green bananas (M. cavendishii var. nanica) as a tool to increase the dietary fiber and phytochemical bioactivity of layer and sponge cakes. Food Chem. 2017, 219, 240-248. [CrossRef]

109. Noort, M.W.; Mattila, O.; Katina, K.; Van der Kamp, J.W. Health Bread: Wholegrain and high fibre breads with optimised textural quality. J. Cereal Sci. 2017, 78, 57-65. [CrossRef]

110. Talens, C.; Álvarez-Sabatel, S.; Rios, Y.; Rodríguez, R. Effect of a new microwave-dried orange fibre ingredient vs. a commercial citrus fibre on texture and sensory properties of gluten-free muffins. Innov. Food Sci. Emerg. Technol. 2017, 44, 83-88. [CrossRef]

111. Verdú, S.; Barat, J.M.; Grau, R. Improving bread-making processing phases of fibre-rich formulas using chia (Salvia hispanica) seed flour. LWT-Food Sci. Technol. 2017, 84, 419-425. [CrossRef]

112. de Oliveira Silva, F.; Miranda, T.G.; Justo, T.; da Silva Frasão, B.; Conte-Junior, C.A.; Monteiro, M.; Perrone, D. Soybean meal and fermented soybean meal as functional ingredients for the production of low-carb, high-protein, high-fiber and high isoflavones biscuits. LWT_Food Sci. Technol. 2018, 90, 224-231. [CrossRef]

113. Rodríguez-García, J.; Sahi, S.S.; Hernando, I. Functionality of lipase and emulsifiers in low-fat cakes with inulin. LWT-Food Sci. Technol. 2014, 58, 173-182. [CrossRef]

114. Laguna, L.; Primo-Martín, C.; Varela, P.; Salvador, A.; Sanz, T. HPMC and inulin as fat replacers in biscuits: Sensory and instrumental evaluation. LWT_Food Sci. Technol. 2014, 56, 494-501. [CrossRef]

115. Graça, C.; Fradinho, P.; Sousa, I.; Raymundo, A. Impact of Chlorella vulgaris on the rheology of wheat flour dough and bread texture. LWT-Food Sci. Technol. 2018, 89, 466-474. [CrossRef]

116. Arufe, S.; Della Valle, G.; Chiron, H.; Chenlo, F.; Sineiro, J.; Moreira, R. Effect of brown seaweed powder on physical and textural properties of wheat bread. Eur. Food Res. Technol. 2018, 244, 1-10. [CrossRef]

117. Różyło, R.; Hameed Hassoon, W.; Gawlik-Dziki, U.; Siastała, M.; Dziki, D. Study on the physical and antioxidant properties of gluten-free bread with brown algae. CYTA-J. Food 2017, 15, 196-203. [CrossRef]

118. Allam, A.Y.; Dolganova, N.V. Effect of the addition of chitosan prepared from green shrimp (Penaeus Semisulcatus) on the sensory characteristics of cupcakes. Carpathian J. Food Sci. Technol. 2017, 9, 117-125. 
119. Kerch, G.; Zicans, J.; Meri, R.M. The effect of chitosan oligosaccharides on bread staling. J. Cereal Sci. 2010, 52, 491-495. [CrossRef]

120. Mogol, B.A.; Gökmen, V. Effect of chitosan on the formation of acrylamide and hydroxymethylfurfural in model, biscuit and crust systems. Food Funct. 2016, 7, 3431-3436. [CrossRef]

121. Vici, G.; Belli, L.; Biondi, M.; Polzonetti, V. Gluten free diet and nutrient deficiencies: A review. Clin. Nutr. 2016, 35, 1236-1241. [CrossRef]

(C) 2019 by the authors. Licensee MDPI, Basel, Switzerland. This article is an open access article distributed under the terms and conditions of the Creative Commons Attribution (CC BY) license (http://creativecommons.org/licenses/by/4.0/). 